\title{
Mineral Resources of the Quigg West Wilderness Study Area, Granite County, Montana
}
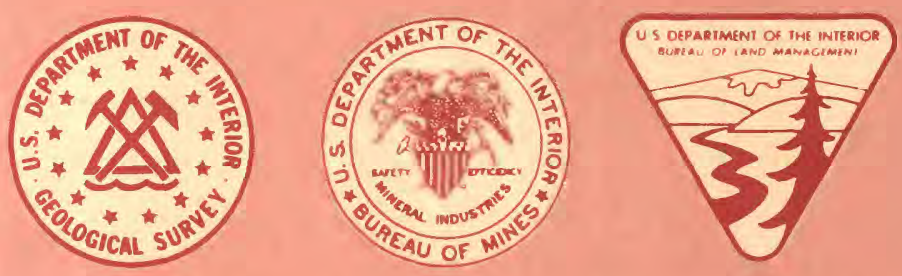

\section{U.S. GEOLOGICAL SURVEY BULLETIN 1724-D}

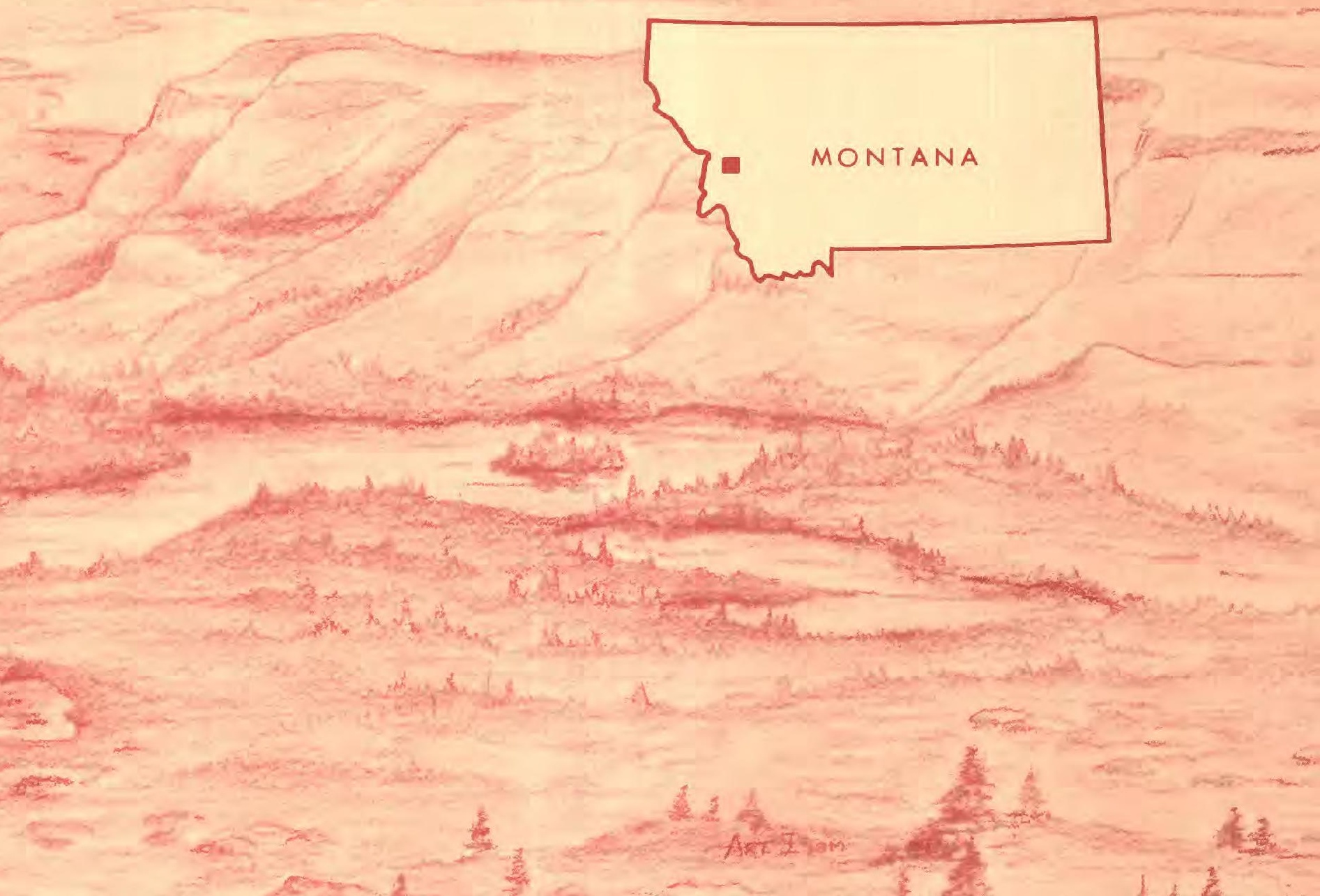



CHAPTER D

\section{Mineral Resources of the Quigg West Wilderness Study Area, Granite County, Montana}

By R.G. TYSDAL and W.F. HANNA

U.S. Geological Survey

D.O. CAPSTICK

U.S. Bureau of Mines 


\section{DEPARTMENT OF THE INTERIOR DONALD PAUL HODEL, Secretary}

\section{U.S. GEOLOGICAL SURVEY}

Dallas L. Peck, Director

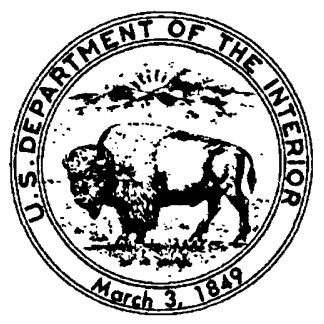

For sale by the

Books and Open-File Reports Section

U.S. Geological Survey

Federal Center

Box 25425

Denver, CO 80225

\section{Library of Congress Cataloging-in-Publication Data}

Tysdal, Russell G.

Mineral resources of the Quigg West Wilderness Study Area, Granite County, Montana.

(Mineral resources of wilderness study areas-southwestern Montana ; ch. D) (U.S. Geological Survey bulletin ; 1724-D)

Bibliography: $p$.

Supt. of Docs. no.: I 19.3:1724-D

1. Mines and mineral resources-Montana-Quigg West

Wilderness. 2. Quigg West Wilderness (Mont.) I. Hanna, William F.,

1938- . II. Capstick, Donald O. III. Title. IV. Series. V. Series: U.S.

Geological Survey bulletin ; 1724-D.

QE75.B no. 1724-D [TN24.M9] 557.3 s 88-600210 


\section{STUDIES RELATED TO WILDERNESS}

\section{Bureau of Land Management Wilderness Study Areas}

The Federal Land Policy and Management Act (Public Law 94-979, October 21, 1976) requires the U.S. Geological Survey and the U.S. Bureau of Mines to conduct mineral surveys on certain areas to determine the mineral values, if any, that may be present. Results must be made available to the public and be submitted to the President and the Congress. This report presents the results of a mineral survey of the Quigg West Wilderness Study Area (MT-074-155), Granite County, Montana. 


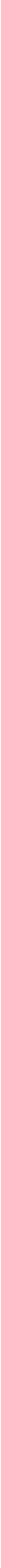




\section{CONTENTS}

Summary D1

Abstract D1

Location, geologic setting, and resources D1

Introduction D3

Investigations by the U.S. Bureau of Mines D3

Investigations by the U.S. Geological Survey D3

Acknowledgments D6

Appraisal of identified resources D6

Mining and mineral exploration history D6

Prospects and mineralized areas D6

Appraisal of mineral resources D6

Assessment of potential for undiscovered resources $\quad$ D7

Geology $\quad$ D7

Geologic setting D7

Description of rock units D7

Geochemistry D9

Analytical methods D9

Results of study D9

Geophysics D12

Methods D12

Gravity anomaly interpretation D12

Magnetic anomaly interpretation D14

Mineral resources D16

Gold and molybdenum D16

Copper and silver D20

Sapphires in placer deposits $\mathbf{D 2 1}$

Barite D22

Energy resources D22

References cited D23

Appendix D27

\section{FIGURES}

1-6. Maps showing:

1. Location of the Quigg West Wilderness Study Area, Granite County , western Montana D2

2. Mineral resource potential, geology, and sample localities, Quigg West Wilderness Study Area D4

3. Regional features of the Butte $1^{\circ} \times 2^{\circ}$ topographic quadrangle, Montana D7

4. Geology of region surrounding Quigg West Wilderness Study Area D8

5. Complete Bouguer gravity anomalies and generalized geology in the vicinity of the Quigg West Wilderness Study Area D15

6. Aeromagnetic anomalies and generalized geology in the vicinity of the Quigg West Wilderness Study Area D16 


\section{TABLES}

1-3. Semiquantitative spectrographic and chemical analyses; Quigg West

Wilderness Study Area, Granite County, Montana:

1. Rock samples D10

2. Stream-sediment samples D13

3. Heavy-mineral concentrate samples

D14 


\title{
Mineral Resources of the Quigg West Wilderness Study Area, Granite County, Montana
}

\author{
By R.G. Tysdal and W.F. Hanna \\ U.S. Geological Survey \\ D.O. Capstick \\ U.S. Bureau of Mines
}

\section{SUMMARY}

\begin{abstract}
A mineral resource survey of the 520-acre Quigg West Wilderness Study Area (MT-074-155) was made in 1986-87 at the request of the U.S. Bureau of Land Management. The study area, in central-western Montana, about 16 miles (mi) west of Philipsburg, was evaluated for its mineral resources (known) and mineral resource potential (undiscovered). No identified (known) resources exist in the wilderness study area and no producing mines exist in or adjacent to it. However, high-grade gold values, as much as 1.24 troy ounces gold per ton, were obtained from one prospect in the southern part of the study area. About 20 claims have been located in the vicinity since the late 1800's, but none are currently active.
\end{abstract}

The southern part of the wilderness study area has a moderate resource potential for gold and molybdenum in quartz veins related to granitic intrusive rocks; the remainder of the area has a low potential for deposits of this type. The northwestern part of the wilderness study area has a moderate resource potential for copper and silver in sandstone-hosted strata-bound deposits; the remainder of the study area has a low resource potential for sandstonehosted copper and silver. Two small areas of gravels in terrace deposits are present in the southern part of the wilderness study area and have a low resource potential for placer gold and placer sapphires. The entire area is rated as having a low resource potential for gold and molybdenum within the interior part of a porphyry molybdenum system; silver-copper-gold within the peripheral part of a porphyry molybdenum system; gold in alluvial deposits of present-day streams; barite in veins; uranium; and geothermal resources. The entire area is rated as having no potential for oil and gas.

\section{Location, Geologic Setting, and Resources}

The Quigg West study area is in the Northern Rocky Mountains and lies in an unnamed range immediately west of the John Long Mountains (fig. 1). The 520-acre study area is on the northeast side of Rock Creek, which flows across the structural grain of the rocks of the region, and the study area ranges from about 4,700 to 6,900 feet ( $\mathrm{ft}$ ) in elevation. The area is near Philipsburg, Montana, from which a paved, then gravel, road provides access to the valley of Rock Creek.

The study area consists mainly of strata of the Middle Proterozoic Belt Supergroup, a sequence of sedimentary rocks that were laid down about 900-1,600 million years (m.y.) ago (see geologic time chart in Appendix). Only the Mount Shields Formation of the Missoula Group of the Belt rocks is exposed in the study area. Mountain-building forces deformed the sedimentary strata prior to about 82 m.y. ago, and resulted in the development of westward-dipping thrust faults that separate repeated (stacked) sequences of strata. Granitic rocks intruded the strata after they were thrustfaulted and are exposed about 1 mi east of the study area, about 3 mi west of it, and may lie concealed in the subsurface immediately west of the study area.

Field and laboratory studies were conducted to assess the identified resources and mineral resource potential of the study area. Geologic mapping was conducted to supplement that done previously in the general area to aid in the determination of possible controls of mineralization. A geochemical study was made, based on spectrographic and chemical analysis of stream sediments and rock samples 


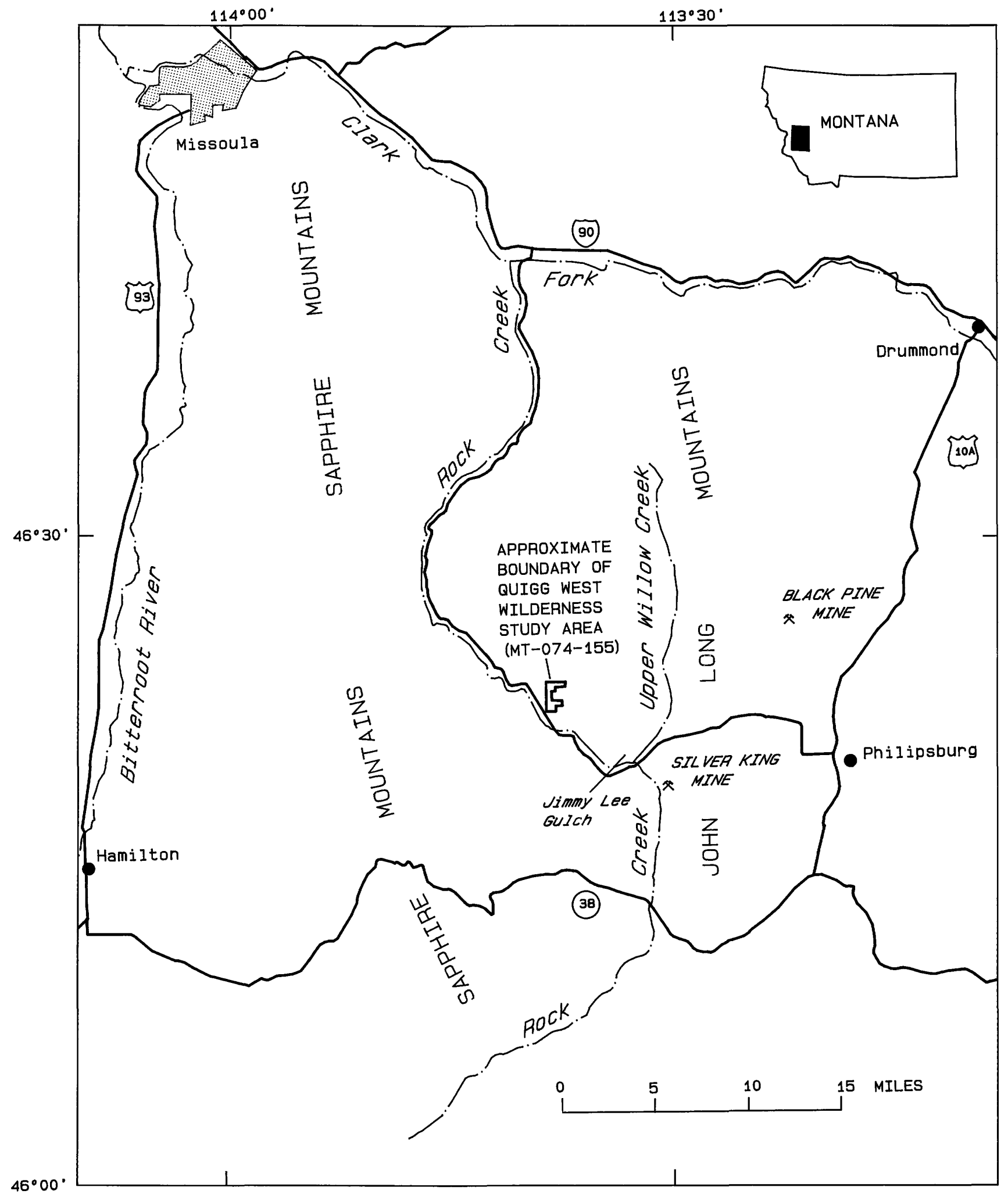

Figure 1. Index map showing location of the Quigg West Wilderness Study Area, Granite County, Montana.

collected by the U.S. Geological Survey (USGS). The U.S. Bureau of Mines (USBM) examined the one prospect found and searched for other mineral occurrences.
No production has been recorded from the wilderness study area, although as many as 20 claims may have been located in or near the area since the late 1800's; no claims 
were active at the time of this study. Production of lode and placer gold has been documented or reported from mines 3-7 mi from the wilderness study area.

The one prospect in the wilderness study area is in an area rated as having moderate resource potential for gold and molybdenum in quartz veins related to granitic intrusive rocks (fig. 2). The prospect workings straddle the southern boundary of the study area and explore a narrow, discontinuous quartz vein. High-grade gold values, as much as $1.24 \mathrm{oz} / \mathrm{ton}$, were obtained at the prospect. Drilling would be required to determine if resources are present.

Geochemical data show anomalous values for copper in Capron Creek in the northwestern part of the study area, but no mineralized rock was found that could be the source of the copper. The source rocks could lie outside the area, or possibly lie concealed beneath talus, alluvium, and colluvium of the wilderness study area. The northwestern part of the study area is rated as having a moderate resource potential for strata-bound, sandstone-hosted copper, and for silver that commonly accompanies copper in this type of deposit.

Two small areas of terrace gravels, remnant deposits of former streams, occur in the southern part of the study area and have a low resource potential for placer gold and placer sapphires. The study area also was evaluated for several other types of deposits that exist within the general region. The entire area is rated as having a low resource potential for gold and molybdenum deposited in the interior part of a porphyry molybdenum system; silver-copper-gold minerals formed in the peripheral part of a porphyry molybdenum system; gold in alluvial deposits of present-day streams; barite in veins; uranium; and geothermal resources. The entire area is rated as having no potential for oil and gas.

\section{INTRODUCTION}

The USGS and the USBM studied the 520-acre Quigg West Wilderness Study Area (MT-074-155) at the request of the U.S. Bureau of Land Management (BLM). In this report the studied area is called the "wilderness study area" or simply the "study area." The study area is located in the Rocky Mountains of centralwestern Montana, in Granite County, about 16 mi west of Philipsburg (fig. 1). It is accessible from a road that is adjacent to Rock Creek, which flows past the southern edge of the study area. The wilderness study area ranges from about 4,700 to $6,900 \mathrm{ft}$ in elevation.

This report presents an evaluation of the mineral endowment (identified resources and mineral resource potential) of the study area and is the product of several separate studies by the USBM and the USGS. Identified resources are classified according to the system of the U.S. Bureau of Mines and the U.S. Geological Survey (1980), which is shown in the Appendix of this report. Identified resources are studied by the USBM. Mineral resource potential is the likelihood of occurrence of undiscovered concentrations of metals and nonmetals, of industrial rocks and minerals, and of undiscovered energy sources (uranium, oil, gas, oil shale, and geothermal sources). It was evaluated using the system of Goudarzi (1984), which is shown in the Appendix of the present report. Classification is according to type of deposit, level of potential, and level of certainty. The mineral resource potential for undiscovered resources is studied by the USGS. In this report, the term "deposit," unmodified, carries no connotation of economic value.

\section{Investigations by the U.S. Bureau of Mines}

Work by the USBM entailed prefield, field, and report preparation phases during 1986-87. Prefield studies included library research and perusal of Granite County, BLM, and Forest Service mining and mineral lease records, and a search of USBM production records. In August and September 1986, the area was searched by ground and air for all prospects and claims indicated by the prefield study to be within the wilderness study area and vicinity. In addition, searches were made for evidence of mining-related activity that may not have been recorded. Workings at the one prospect found were sampled and mapped, and reconnaissance placer samples were taken of alluvium at the mouths of Capron Creek and Sheep Gulch (fig. 2), which drain the wilderness study area. Results of these studies are presented in Capstick (1987) and are summarized in the present report.

Ten rock (lode) and three alluvial (placer) samples were collected. The rock samples were analyzed for gold and silver by fire assay; some were analyzed for copper, lead, zinc, or molybdenum by other methods. The samples were also analyzed for 24 elements by the induction-coupled plasma (ICP) method.

Alluvial samples were concentrated in the field by hand-panning and further concentrated on a laboratorysize Wilfley ${ }^{1}$ table. The concentrates were then examined for gold and other heavy-metal content.

Sample analytical results are on file at U.S. Bureau of Mines, Western Field Operations Center, E. 360 Third Ave., Spokane, WA 99202.

\section{Investigations by the U.S. Geological Survey}

During the summers of 1986-87, stream-sediment and rock samples were collected from the area and analyzed chemically and spectrographically. These data

\footnotetext{
${ }^{1}$ Trade and company names are used for descriptive purposes only and do not imply endorsement by the U.S. Bureau of Mines.
} 


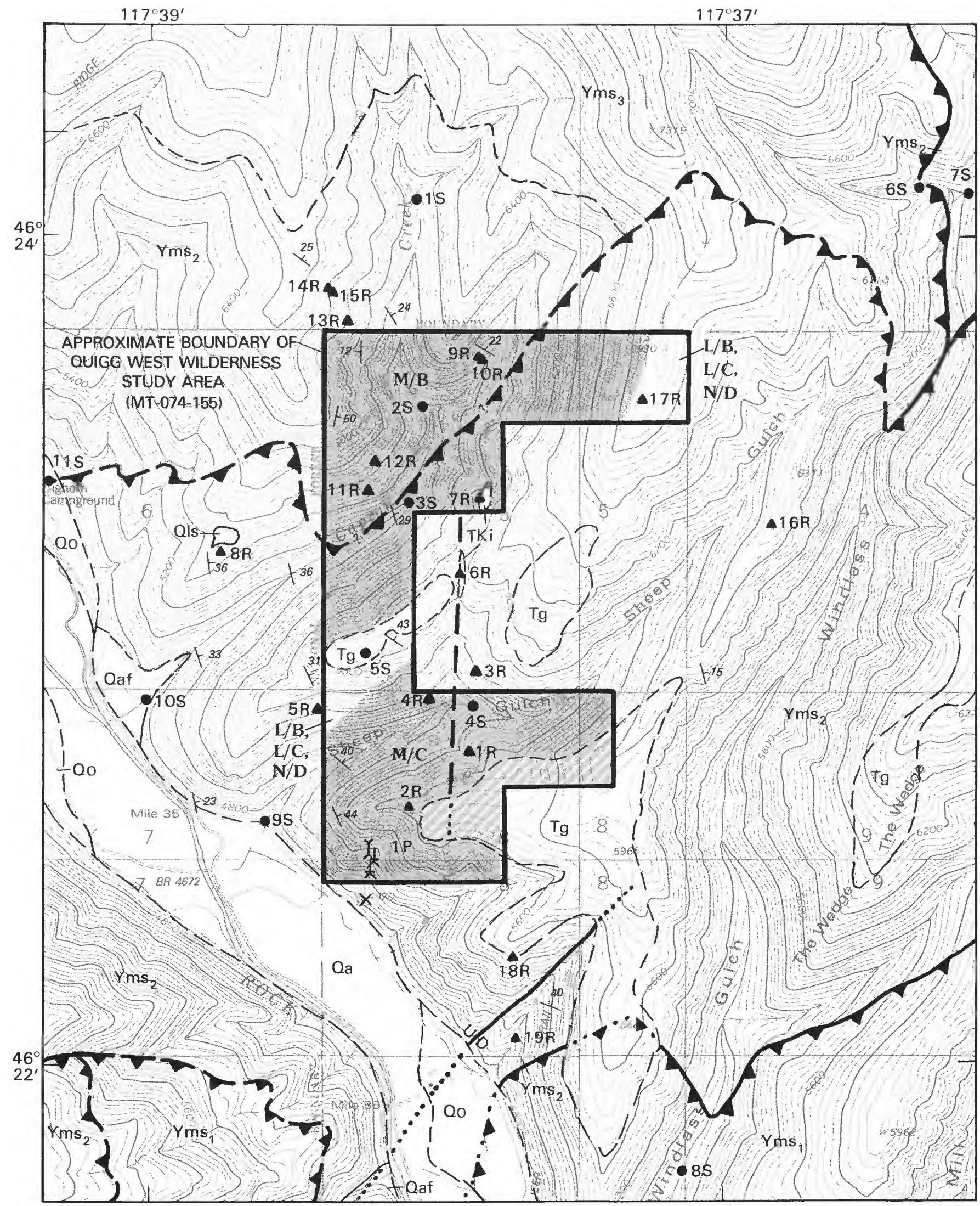

Figure 2 (above and facing page). Map showing mineral resource potential, geology, and sample localities, Quigg West Wilderness Study Area, Granite County, Montana. 
Geologic terrane having moderate resource potential-

For gold and molybdenum in quartz veins related to granitic intrusive rocks

For sandstone-hosted strata-bound copper and silver, pattern shows the part of the terrane that is concealed by terrace gravels

L/B,C Geologic terrane having low resource potential-

For the entire area, except as shown above:

Gold and molybdenum in quartz veins related to granitic intrusive rocks; sandstone-hosted strata-bound copper and silver

For the entire area:

Gold and molybdenum in interior part of porphyry molybdenum system; silver, copper, and gold in peripheral part of porphyry molybdenum system; placer gold in gravels of presently active streams; barite in veins

Uranium; geothermal resources; placer gold in terrace gravels; placer sapphires in terrace gravels

N/D Geologic terrane having no resource potential-

For the entire area:

Oil and gas

Levels of certainty

Available information suggests level of resource

Available information gives good indication of level of mineral resource potential

Available information clearly defines level of mineral resource potential

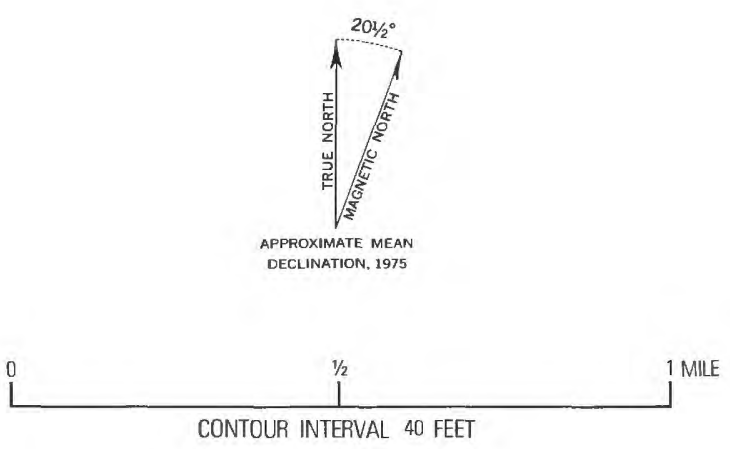

Base from US. Geological Survey Alder Gulch, Cornish Gulch and Quigg Peak, 1975 .

Stoney Creek, 1974
Geology from Wallace and others (1986),

C A. Wallace, and unpublished data

\footnotetext{
..... $\frac{U}{D}$ Fault-U, upthrown side; D, downthrown side. Dotted where concealed

..?. Thrust fault-Sawteeth on upper plate; queried where uncertain; dotted where concealed

15 Strike and dip of beds

- Sample locality-Stream sediment, heavy-mineral concentrate, or terrace gravel

$\Delta^{2 R} \quad$ Sample locality-Rock

Prospect-Showing caved adits, trench, and pit

$\begin{array}{ll}+^{1 P} & \text { Caved adit } \\ >< & \text { Trench } \\ \times & \text { Pit }\end{array}$
}

CORRELATION OF MAP UNITS

\begin{tabular}{|c|c|c|c|}
\hline $\mathrm{Oa}$ & Qls & Holocene & \\
\hline Qaf & Qo & & \\
\hline \multicolumn{4}{|c|}{ Unconformity } \\
\hline \multicolumn{2}{|c|}{$\mathrm{Tg}$} & & TERTIARY \\
\hline \multicolumn{4}{|c|}{ Unconformity } \\
\hline \multicolumn{2}{|c|}{ TKi } & & \multirow[t]{2}{*}{ CRETACEOUS } \\
\hline \multicolumn{3}{|c|}{ Unconformity } & \\
\hline \multicolumn{2}{|c|}{$\mathrm{Yms}_{3}$} & & \multirow{3}{*}{$\begin{array}{c}\text { MIDDLE } \\
\text { PROTEROZOIC }\end{array}$} \\
\hline \multicolumn{2}{|c|}{$\mathrm{Yms}_{2}$} & & \\
\hline \multicolumn{2}{|c|}{$\mathrm{Yms}_{\mathbf{1}}$} & & \\
\hline
\end{tabular}

LST OF MAP UNITS

Oa

Ols

Qaf

Oo

$\mathrm{Tg}$

TKi

$\mathrm{Yms}_{3}$

$\mathrm{Yms}_{2}$

$\mathrm{Yms}_{1}$
Alluvium (Holocene)

Landslide (Holocene)

Alluvial fan (Quaternary)

Glacial outwash (Quaternary)

Terrace deposits (Tertiary)

Dacite dike (Tertiary or Late Cretaceous)

Mount Shields Formation (Middle Proterozoic)

$$
\text { Upper member }
$$

Middle member

Lower member 
were supplemented by analyses of stream sediment, heavy-mineral concentrates of stream sediments, and rock samples collected from the vicinity of the study area by Campbell and others (1982a). No new geophysical measurements were made because adequate data had been collected recently for the region of the Butte $1^{\circ} \times 2^{\circ}$ quadrangle, in which the study area lies. Geologic mapping was undertaken to supplement that previously conducted within the study area by Wallace and others (1986) and C.A. Wallace (unpublished data).

\section{Acknowledgments}

Jim Sheldon, geologist, Butte BLM District Office, provided author Capstick with pertinent mineral and mining information. John R. Benham, Alan R. Buehler, Martin D. Conyac, Phillip R. Moyle, and Thomas J. Peters, U.S. Bureau of Mines, assisted with the USBM field investigation. Authors Tysdal and Hanna thank C.A. Wallace and J.E. Elliott, both of the USGS, for providing manuscripts that were in review and for other unpublished data as well. Discussions of the regional geology and mineral resources of the region were most useful.

\section{APPRAISAL OF IDENTIFIED RESOURCES}

\section{By D.O. Capstick \\ U.S. Bureau of Mines}

\section{Mining and Mineral Exploration History}

There has been no recorded production from the Quigg West Wilderness Study Area.

The Bagdad mine, $3 \mathrm{mi}$ to the west, possibly produced some gold in the late 1890's. Exploration was underway, and mine workings were being rehabilitated in 1987. Remains of milling facilities and numerous workings indicate that gold was produced from the Crescent mine, $4.5 \mathrm{mi}$ to the southwest. The Silver King mine, $7 \mathrm{mi}$ to the southeast, has had production valued at about $\$ 2$ million in gold and silver during the last two decades; no production is currently (1986) being reported.

Placer gold is reported (Lyden, 1948; Wallace and others, 1981) to have been mined nearby from Holocene gravels in Rock Creek and some of its tributaries.

Deposits or occurrences of placer gold, titanium, corundum, and sapphires, and lode gold, zinc, silver, copper, tungsten, molybdenum, antimony, fluorspar, manganese, rare earths, uranium, vermiculite, and pumice have been prospected or mined 3-15 $\mathrm{mi}$ from the study area in the same or similar rock formations.

Mining claim notices give only vague descriptions for claims in or near the wilderness study area. Consequently, the actual number of claims is estimated at 5-20; the earliest recorded dates are from the late 1800 's, and none are current. Several unorganized mining districts that may have enclosed all or a part of the study area were identified, but descriptions were inexact. The unorganized Rock Creek mining district, encompassing much of the main Rock Creek drainage, is the only name in current use.

\section{Prospects and Mineralized Areas}

Four workings were found at a prospect that straddles the south boundary of the wilderness study area. They consist of two caved adits, estimated from the size of the dumps to have been $50 \mathrm{ft}$ and $250 \mathrm{ft}$ long, a $40-\mathrm{ft}$ trench, and a small pit (fig. 2). They expose or were driven into an apparent fault zone containing a goldbearing, 7-inch-thick quartz vein. The workings and the one accessible vein exposure suggest that the mineralized fault zone, containing the narrow, discontinuous quartz vein, extends about $700 \mathrm{ft}$ and is steeply dipping. Ten samples assayed from 0.004 to $1.244 \mathrm{oz}$ gold/ton, nil to $0.45 \mathrm{oz}$ silver/ton, and nil to 0.02 percent molybdenum; one of the samples also contained 0.39 percent copper (Capstick, 1987).

Alluvial samples, taken near the mouths of Capron Creek and Sheep Gulch which drain the study area (fig. 2 ), showed no placer gold or other significant heavy minerals; 30 acres of perched Tertiary-age gravel in the southeast part of the study area is drained by Sheep Gulch.

\section{Appraisal of Mineral Resources}

No mineral resources were identified in the wilderness study area. Although samples taken from mineral-rich stockpiles at the only prospect have good gold values, caving and sloughing precluded extensive sampling of in-place material, and field evidence indicates that the mineralized zone is too narrow and discontinuous to constitute resources. Drilling would be required to determine if the mineralized zone increases in size and persistence with depth, thereby delineating possible resources.

The Tertiary-age gravel terranes in the study area's southeast corner are similar to gravel occurrences elsewhere in the vicinity, some of which contain placer gold. One reconnaissance pan sample from the mouth of Sheep Gulch, which drains the gravel, showed no placer gold. 


\section{ASSESSMENT OF POTENTIAL FOR UNDISCOVERED RESOURCES}

\section{By R.G. Tysdal and W.F. Hanna U.S. Geological Survey}

\section{Geology}

\section{Geologic Setting}

The Quigg West Wilderness Study Area is in an unnamed range of mountains directly west of the John Long Mountains (fig. 1). It is underlain by strata of the Belt Supergroup of Middle Proterozoic age, of which only quartzite and minor argillite of the Mount Shields Formation crop out. The total thickness of the formation in this part of Montana is 13,000-15,000 ft (C.A. Wallace, written commun., 1987). Dacite of Cretaceous or Tertiary age forms two dike-like intrusive bodies in and directly adjacent to the study area. Unconsolidated deposits of late Tertiary and Quaternary age occur locally within the study area.

Strata of the general region form part of the Sapphire thrust plate, an eastward-convex part of the overthrust belt of western Montana (Ruppel and others, 1981). The western part of the Sapphire plate consists of a terrane of stacked thrust sheets, and the eastern part consists of a frontal zone of anastamosing imbricated thrust faults (Lidke and others, 1987; Wallace and others, in press) (see fig. 3). In a preliminary interpretation of the structural framework of the region, Wallace (in Ruppel and others, 1981) used the name Rock Creek subplate for the general region of the wilderness study area. The new terminology reflects substantial revision of the boundaries of the Sapphire plate and its internal subdivision.

The following descriptive and interpretative material is from Wallace and others (in press). Individual sheets in the thrust sheet terrane are composed of distinct lithologic sequences bounded by decollements, which are generally parallel to bedding. The thickness of thrust sheets ranges from about 5,000 to $15,000 \mathrm{ft}$. The stacked thrust sheets end in imbricate thrust faults that form the leading edge of the Sapphire plate. The plate was emplaced during regional compression, in three main phases: (1) emplacement of thrust sheets at the same time as the frontal parts of the sheets were being imbricated in the frontal zone; (2) folding of the thrust sheets; and (3) displacement along zones of younger imbricate thrust faults. The entire sequence was later cut by steeply dipping faults. Granitic stocks and batholiths intruded the Sapphire plate, mostly after emplacement of the plate.

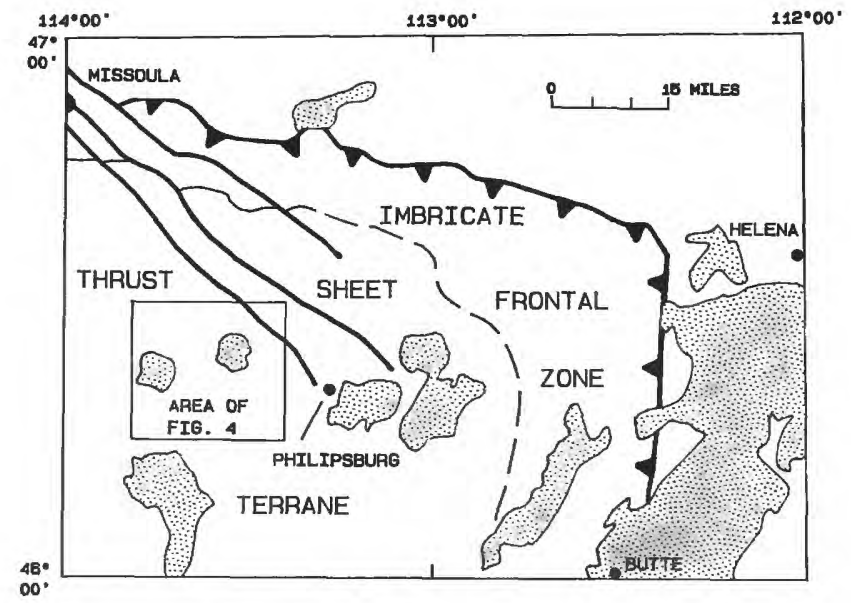

Figure 3. Map showing structural setting of region surrounding the Quigg West Wilderness Study Area, Montana. Thrust sheet terrane and imbricate frontal zone are described in text. Intrusive rocks are shown by shaded pattern. Map area shown is that of Butte, Montana, $1^{\circ} \times 2^{\circ}$ topographic quadrangle.

Strata of the wilderness study area and the adjacent region are part of one thrust sheet within the thrust sheet terrane. The thrust faults shown on figure 2 are some of the younger imbricate faults within the sheet. Outcrops of the Mount Shields Formation are part of this sheet, but regional data of Ruppel and others (1981), Wallace and others (1986), and unpublished data of Wallace indicate that other thrust sheets lie beneath the study area and that they contain Belt strata of the Snowslip Formation of the Missoula Group and Helena (or the equivalent Wallace) Formation, respectively.

The study area lies $1 \mathrm{mi}$ west of the Miners Gulch stock and 3 mi east of the Big Spring Creek stock (fig. 4); both stocks truncate the thrust faults of the region. The Miners Gulch stock has yielded a potassium-argon age of about 81 m.y. (Wallace and others, in press). The Big Spring Creek stock has not been dated radiometrically, but it is considered to be about 73 m.y. old (C.A. Wallace, oral commun., 1987), because the stock is a zoned intrusive much like the Sapphire batholith (12 mi to the south) that has been dated at $73 \mathrm{~m}$.y. (Wallace and others, 1982). Zoning of the Sapphire batholith shows an outer rim composed of hornblende-biotite granodiorite and monzogranite, and a small inner core composed of muscovite-biotite granodiorite and monzogranite (Wallace and others, 1982, 1984); the Big Spring Creek stock shows the same compositional zonation (C.A. Wallace, oral commun., 1987).

\section{Description of Rock Units}

Rock units within or near the Quigg West Wilderness Study Area are described next, with letter symbols as shown on figure 2 . 


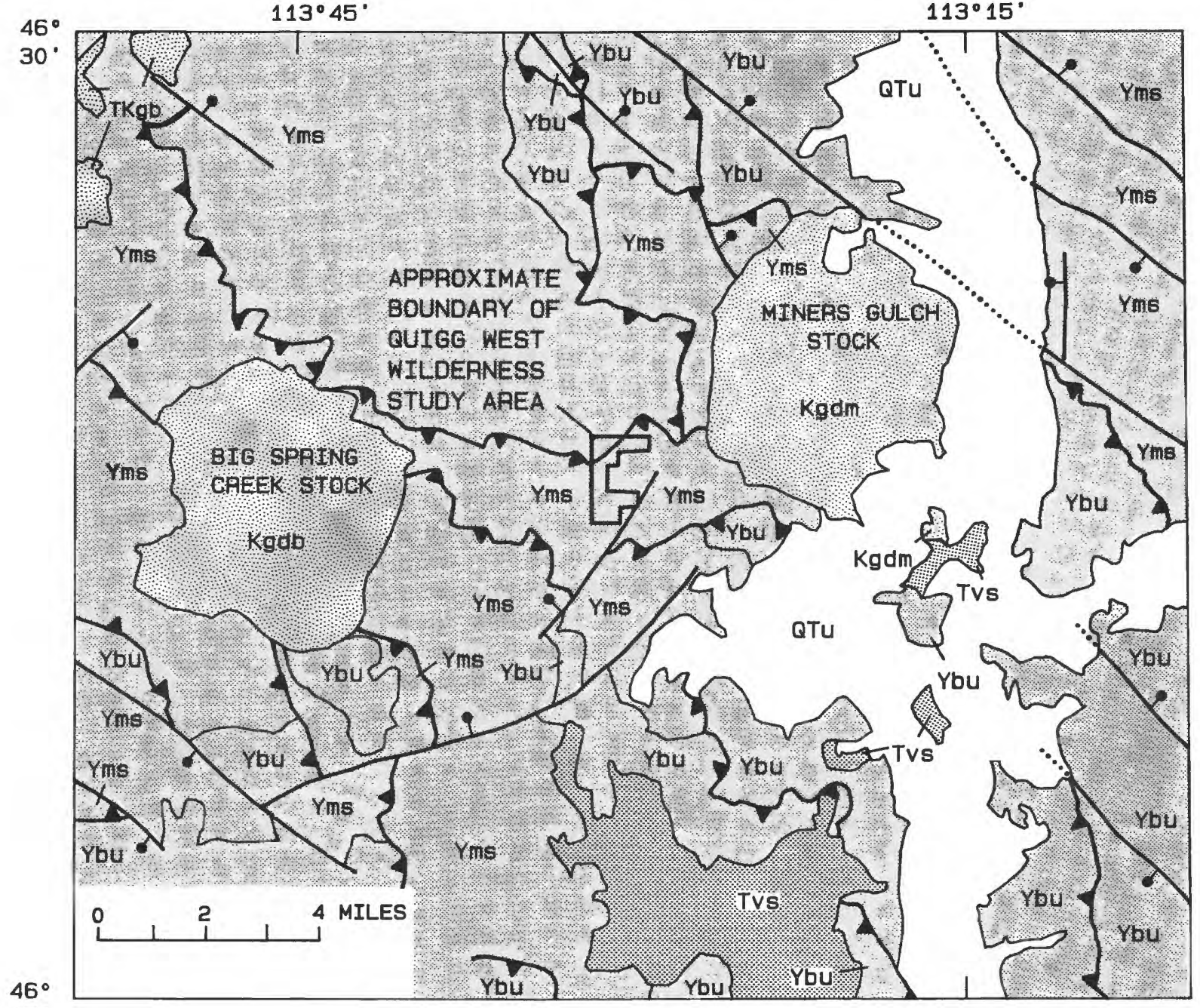

$15^{\circ}$

\section{EXPLANATION}

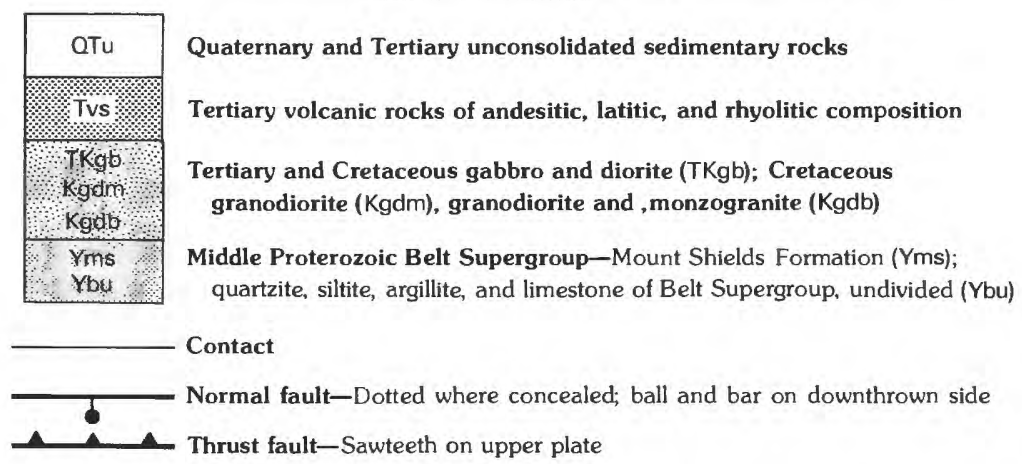

Figure 4. Generalized geologic map of region that contains the study area. Geology generalized from Wallace and others (1986).

Mount Shields Formation (Middle Proterozoic) of the Missoula group of the Belt Supergroup.-Three informal members.

Lower member $\left(\mathrm{Yms}_{1}\right)$.-Alternating quartzite and argillite in sequences that each range from about 50 to $100 \mathrm{ft}$ thick. Quartzite is pink, flaggy, fine- to mediumgrained arkose and quartzite. Argillite sequences are composed of rhymthically interbedded red argillite and buff to pink siltite. Ripples, mud cracks, and fluid-escape structures are common in argillite sequences, crossbeds 
are common in quartzite sequences. Regional thickness of the unit is 3,000-3,500 ft. This unit does not crop out in wilderness study area, but is shown on the geologic map of figure 2. The description is from C.A. Wallace (written commun., 1987).

Middle member $\left(\mathrm{Yms}_{2}\right)$.-Gray, buff, and pale reddish brown fine- to medium-grained, and locally coarse-grained quartzite and arkosic quartzite. Beds are commonly 1-3 ft thick and graded; the upper part is fine grained and capped by layer or thin unit of argillite. Ripped-up clasts of argillite are present locally in the basal part of the overlying bed. Locally contains trough crossbeds, as much as $\mathbf{3 f t}$ across. Forms blocky outcrops. Data of C.A. Wallace (written commun., 1987) indicates regional thickness of the unit is about $7,000 \mathrm{ft}$.

Upper member $\left(\mathrm{Yms}_{3}\right)$.-Tan, brown, and maroon arkosic siltite and fine-grained quartzite, and minor interbedded gray-green argillite. Crossbeds and oscillatory ripple marks are present locally. Beds generally are less than $3 \mathrm{ft}$ thick, but some are several feet thick. Regional thickness of the unit is about $3,500 \mathrm{ft}$ (C.A. Wallace, written commun., 1987).

Dacite dike of Late Cretaceous or Tertiary age (TKi).-Medium-gray, poorly exposed biotite dacite that forms dike-like intrusive bodies along a fault zone. Its age is inferred from data and interpretations of Loen and others (in press).

Terrace deposits of Tertiary age (Tg).-Unconsolidated deposits of clay. silt, sand, gravel, cobbles, and boulders that form a veneer on some ridge crests. Cobbles and boulders are mainly composed of maroon, well-rounded, fine- to coarse-grained quartzite. Deposits are isolated remnants of terrace gravels that probably were laid down by an ancestral stream.

Glacial outwash deposits of Quaternary age (Qo).Unconsolidated rock materials transported in streams that were active during time when glaciers existed in the general area.

Alluvial fan of Quaternary age (Qaf).-Fan-shaped alluvial deposits of unconsolidated clay, silt, sand, gravel, and boulders. Clasts are angular to well rounded.

Landslide deposits of Holocene age (Qls).-Unconsolidated deposits of silt, sand, and gravel that have moved downslope as the result of water saturation and the influence of gravity.

Alluvium of Holocene age (Qa).-Unconsolidated clay, silt, sand, gravel, and boulders of present-day streams and flood plains of the streams. Larger clasts tend to be rounded or well rounded.

\section{Geochemistry}

Geochemical data for use in this study were obtained from stream-sediments (11 samples), heavymineral concentrates (4 samples), and rocks (19 samples) collected during the summers of 1986-87, and from the regional sample data set of Campbell and others (1982a, b). Geochemical data used for the mineral deposit models largely came from Loen and others (in press), J.E. Elliott (unpublished data) and Campbell and others (1982a).

\section{Analytical Methods}

Stream-sediment samples collected during this study and that of Campbell and others (1982a) were obtained from active and intermittent streams. At each site a composite sample of fine detritus was collected from several places within the stream bed and later air-dried and sieved for analysis. Heavy-mineral concentrates of stream sediments, and the sample of Tertiary gravel, were panned from coarser detritus believed to represent a fairly high-energy depositional environment.

Rock samples were collected (1) to identify and evaluate places where obvious mineralized or hydrothermally altered rock exist within the wilderness study area, and (2) to determine background abundances of elements to help evaluate the stream-sediment samples. The samples were taken as representative composites of chips from outcrops, except for three samples collected from float (indicated in table 1). ${ }^{7}$

All samples were analyzed for 31 elements using a six-step, direct-current arc, optical-emission, spectrographic method (Grimes and Marranzino, 1968). Stream-sediment samples were sieved through an 80mesh (177-micrometer) screen, and a split of the portion passing through the sieve was analyzed. A split of each crushed and ground rock sample, and a small split of each heavy-mineral concentrate sample, also were analyzed by this method. Atomic-absorption analyses for gold were made on the remainder of each concentrate sample, and on each rock sample, using the method of Thompson and others (1968). Splits of the rock samples also were analyzed for antimony, arsenic, bismuth, cadmium, and zinc using the partial extraction, atomicabsorption method of Viets and others (1984), in which the readily soluble portions of these elements are dissolved and analyzed.

\section{Results of Study}

Anomalous geochemical data are briefly described in this section. The characteristics of the anomalies and their implications are discussed more fully in the section of this report entitled "Mineral Resources."

Anomalous concentrations of gold, silver, molybdenum, arsenic, and barium (table 1, fig. 2) were found in rocks from the southeastern part of the wilderness study area in the valley of Sheep Gulch. The 


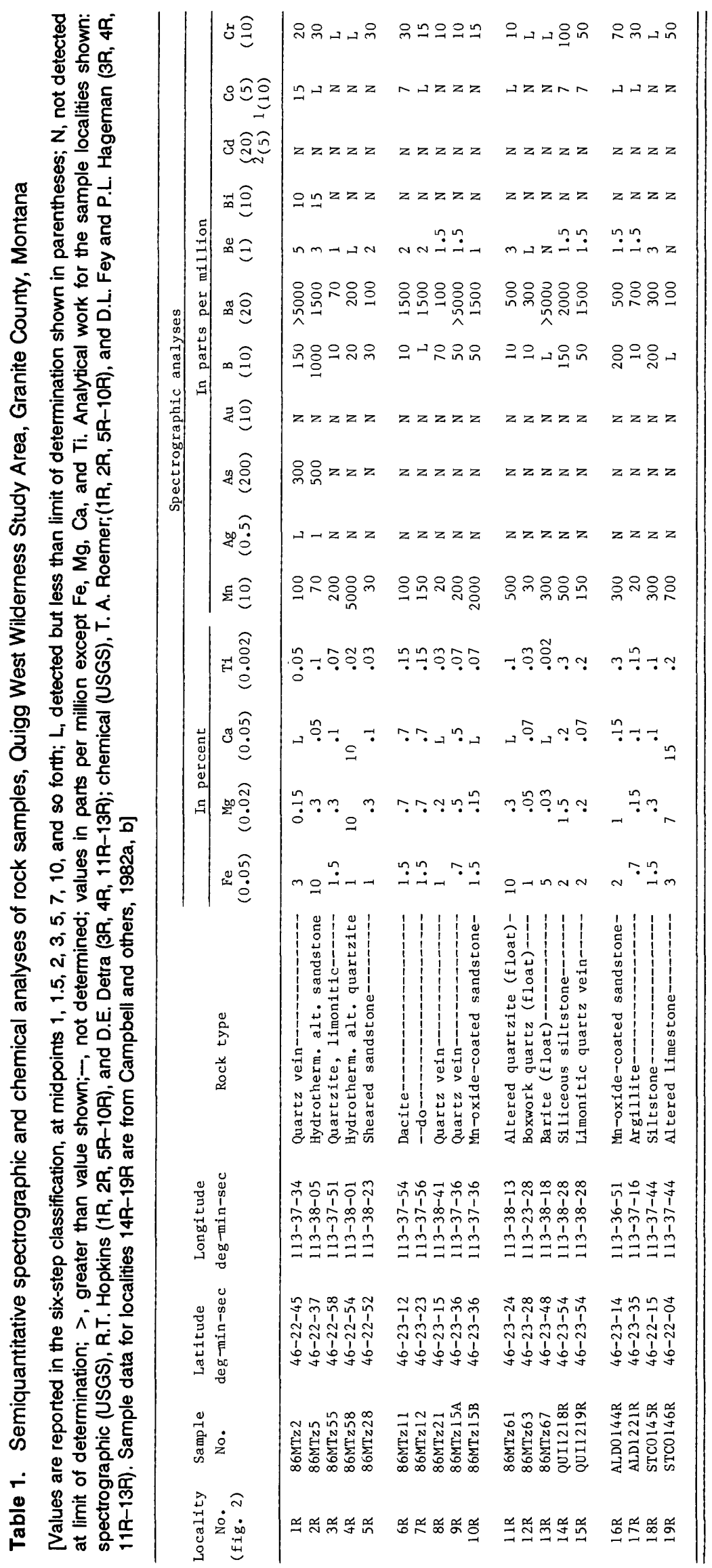




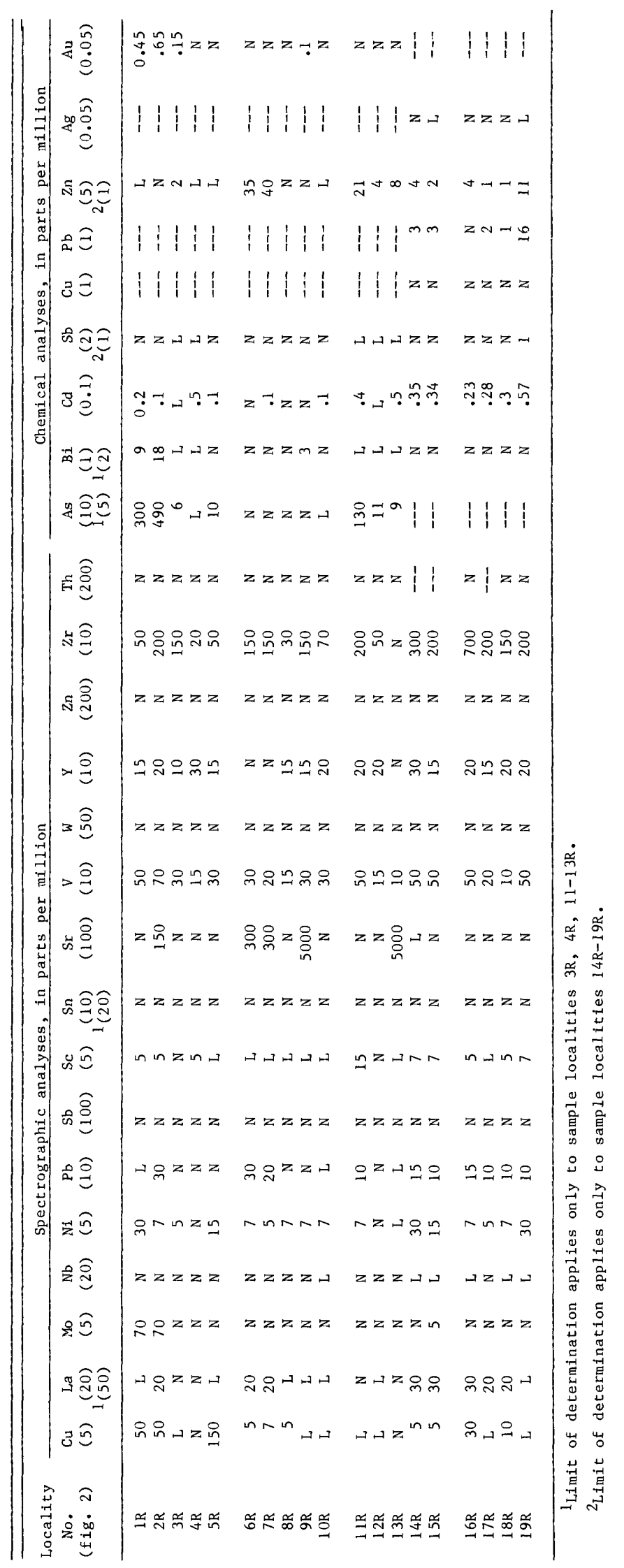


area, here called the Sheep Gulch anomaly, contains mineralized quartz veins and hydrothermally altered country rock and is the site of a prospect. One streamsediment sample from locality $4 \mathrm{~S}$ from within this anomaly yielded a low value ( $0.1 \mathrm{ppm})$ for gold (table 2$)$. A heavy-mineral concentrate sample from locality $8 \mathrm{~S}$, about $1 \mathrm{mi}$ southeast of the study area (table 3, fig. 2), yielded a value of $3.94 \mathrm{ppm}$ gold. This sample is from Windlass Gulch and could represent gold concentrated from rocks of the Sheep Gulch anomaly of the wilderness study area, from terrace gravels that cap the anomaly area, or from rocks from an extensive area of terrain outside the study area.

The stream-sediment samples from localities $2 S$ and $3 \mathrm{~S}$ show anomalous values for copper in Capron Creek (table 2, fig. 2). These anomalies could represent strata-bound copper- and silver-sulfide deposits in the drainage area because the stream drains strata that are potential host rocks for such mineral deposits. The stream-sediment samples have the geochemical characteristics that Harrison and others (1986) showed are useful in defining areas of potential for strata-bound copper- and silver-sulfide deposits: they contain anomalous amounts of copper, with or without silver or lead; none, however, contain anomalous amounts of bismuth, molybdenum, antimony, or zinc.

Barium in stream-sediment samples from the general region of the wilderness study area commonly shows values as high as 1,500-2,000 ppm, as revealed by our geochemical data and that of Campbell and others (1982a). The high value (greater than $10,000 \mathrm{ppm}$ ) of barium in the sample from locality $10 \mathrm{~S}$ (table 3 ) likely represents barium derived from barite float that was found at locality 13R directly north of the wilderness study area. No sulfide elements were detected in either the concentrate sample or the barite float.

\section{Geophysics}

\section{Methods}

The Quigg West Wilderness Study Area and surrounding region are covered by regional gravity and aeromagnetic surveys having sufficient resolution to define anomalies of one or more square miles in areal extent. Gravity data are in the form of a terrain-corrected Bouguer gravity anomaly map (Hassemer and Hanna, 1982; Hassemer, 1984) and are based largely on about 50 observation points within or adjacent to the map area shown on figure 5 (Hassemer and Lidke, 1986). Aeromagnetic data are in the form of an anomaly map (U.S. Geological Survey, 1984) contoured from measurements made along flight lines in an east-west direction, spaced 1 mi apart, at a barometric elevation of $9,000 \mathrm{ft}$, and are based on 13 flight lines within or adjacent to the map area of figure 6 .

\section{Gravity Anomaly Interpretation}

The gravity anomaly map (fig. 5) shows that the Quigg West Wilderness Study Area is flanked by two elongate lows-one shown in the eastern half of figure 5 and the other in the western half-separated by a broad high. The study area is located on a locally flattened part of the eastern flank of the western gravity low. The eastern (2-minima) gravity low, which has a northerly trend, is mainly associated with low-density Tertiary and Quaternary unconsolidated deposits. However, the gravity minimum within the northern part of the low is unexpectedly associated with part of the Cretaceous Miners Gulch stock, which is composed principally of hornblende-biotite granodiorite that has somewhat higher density than hornblende-poor granodiorite. The western gravity low, which trends northwest, is unexpectedly associated with Middle Proterozoic sedimentary rocks of the Belt Supergroup and with part of the Cretaceous Big Spring Creek stock, which is composed principally of monzogranite. The intervening high is associated with the western two-thirds of the Miners Gulch stock and the adjacent terrane of Belt Supergroup strata, which includes the wilderness study area.

The eastern low, when considered in relation to mapped geology and inferred average densities based on measurements made in nearby areas, suggests several possibilities, which are as follows. (1) The Miners Gulch stock is laccolithic in part; the eastern third of the mapped exposures are composed only of a very thin layer of granodiorite that extends over lower density Belt strata. (2) The stock may be cut at depth by a westwarddipping thrust fault of the Sapphire thrust plate; much of the eastern part of the stock is thinner in the subsurface than the western part. (3) Field studies of Loen and others (in press) show that this part of the stock is intruded by a younger, low (or lower) density leucocratic porphyritic granodiorite, is pervasively altered, and is associated with anomalous concentrations of molybdenum. Neither possibility (1) nor (2) is supported by field evidence. The lower density intrusive body, and the associated pervasive silicification, is the most likely cause of this gravity low. The western gravity low also may be due to an altered, low-density intrusive body at depth. Although the southwestern flank of this low might be explained in part by an eastward decrease in density of the zoned Big Spring Creek stock as granodiorite becomes monzogranite, it is unlikely that the central part and northeastern flank of the low are due to lateral changes in density of Belt strata.

A clue to the cause of the western gravity low, and the unexplained part of the eastern low, lies in a region about $5 \mathrm{mi}$ south of the area of figure 5 , where the eastern and western gravity lows converge. The resulting broad low marks their convergence and clearly is 

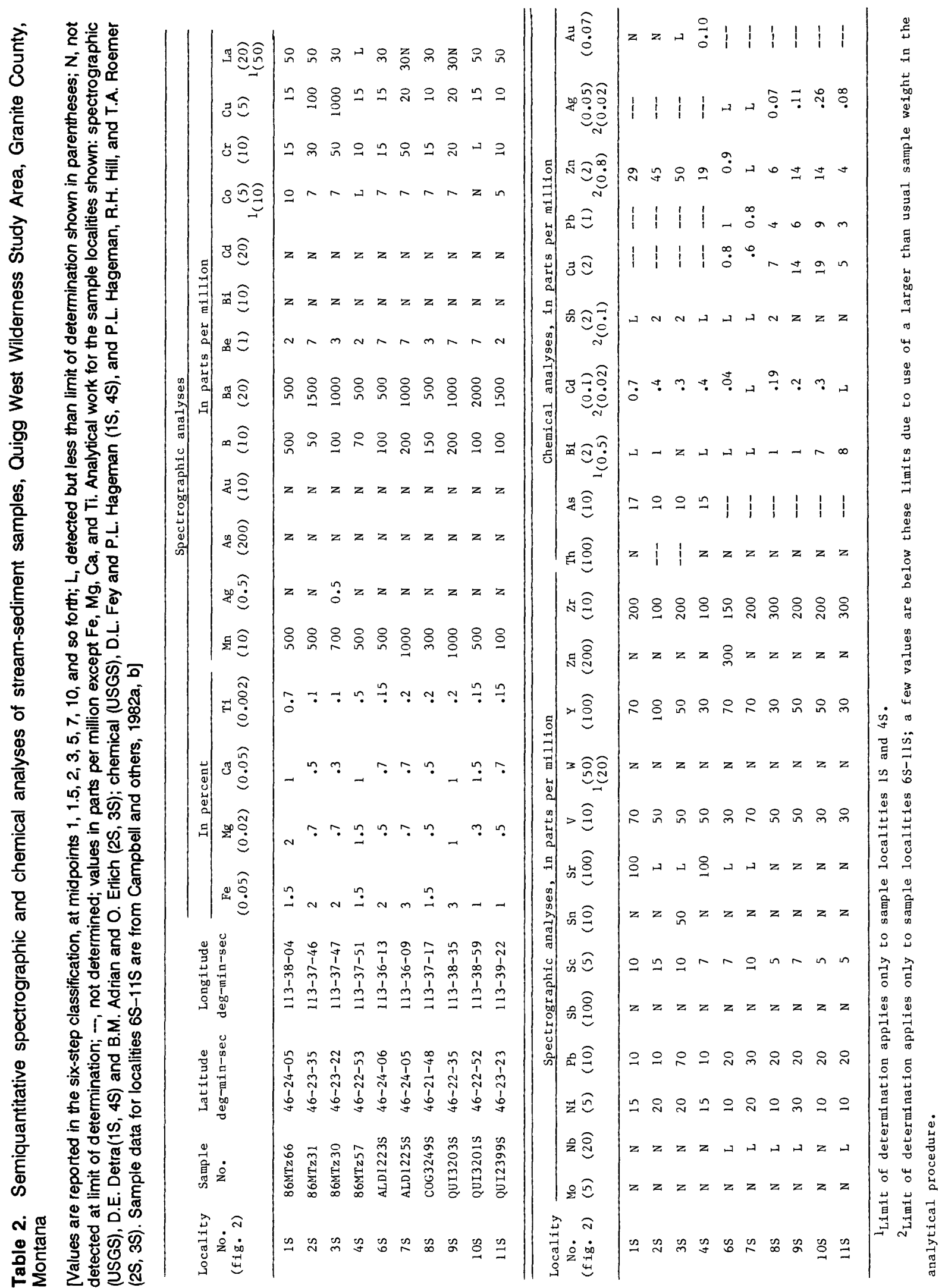
Table 3. Semiquantitative spectrographic and chemical analyses of heavy-mineral concentrate samples, Quigg West Wilderness Study Area, Granite County, Montana

[Values are reported in the size-step classification, at midpoints $1,1.5,2,3,5,7,10$, and so forth; $L$, detected but less than limit of determination shown in parentheses; $\mathrm{N}$, not detected at limit of determination; values in parts per million except $\mathrm{Fe}, \mathrm{Mg}, \mathrm{Ca}$, and Ti. Analytical work for the sample localities shown: spectrographic (USGS), D.E. Detra (5S); chemical (USGS), P.L. Hageman (5S). Sample data for localities 8S-10S are from Campbell and others, 1982a, b]

\begin{tabular}{|c|c|c|c|c|c|c|c|c|c|c|c|c|}
\hline \multirow{2}{*}{$\begin{array}{l}\text { Locality } \\
\text { No. } \\
\text { (fig. 2) }\end{array}$} & \multirow{2}{*}{$\begin{array}{c}\text { Sample } \\
\text { No. }\end{array}$} & \multirow{2}{*}{$\begin{array}{l}\text { Latitude } \\
\text { deg-min-sec }\end{array}$} & \multirow{2}{*}{$\begin{array}{l}\text { Longitude } \\
\text { deg-min-sec }\end{array}$} & \multicolumn{4}{|c|}{ Analyses, in percent } & \multicolumn{5}{|c|}{ Analyses, in parts per million } \\
\hline & & & & $\begin{array}{c}\mathrm{Fe} \\
(0.1)\end{array}$ & $\begin{array}{c}\mathrm{Mg} \\
(0.05)\end{array}$ & $\begin{array}{l}\mathrm{Ca} \\
(0.1)\end{array}$ & $\begin{array}{c}\mathrm{Ti} \\
(0.005)\end{array}$ & $\begin{array}{c}\text { Mn } \\
(20)\end{array}$ & $\begin{array}{l}\mathrm{Ag} \\
(1)\end{array}$ & $\begin{array}{l}\text { As } \\
(200)\end{array}$ & $\begin{array}{c}\mathrm{Au} \\
(10)\end{array}$ & $\begin{array}{c}\text { B } \\
(20)\end{array}$ \\
\hline $5 S$ & $86 \mathrm{MTz} 53$ & $46-23-00$ & $113-38-13$ & 2 & 0.7 & 0.2 & 1 & 700 & $\mathrm{~N}$ & $\mathrm{~N}$ & $\mathrm{~N}$ & 70 \\
\hline $8 \mathrm{~S}$ & $\operatorname{cog} 3293 P$ & $46-21-48$ & $113-37-17$ & 3 & .3 & .15 & 0.7 & 150 & $\mathrm{~N}$ & $\mathrm{~N}$ & $\mathrm{~N}$ & 300 \\
\hline $10 \mathrm{~s}$ & QUI3200P & $46-22-52$ & $113-38-59$ & 1.5 & .3 & .15 & .5 & 20 & $\mathrm{~L}$ & $\mathrm{~N}$ & $\mathrm{~N}$ & 100 \\
\hline
\end{tabular}

\begin{tabular}{|c|c|c|c|c|c|c|c|c|c|c|c|c|}
\hline \multirow{3}{*}{$\begin{array}{l}\text { Locality } \\
\text { No. } \\
\text { (fig. 2) }\end{array}$} & \multicolumn{12}{|c|}{ Analyses, in parts per million } \\
\hline & \multicolumn{12}{|c|}{ Spectrographic } \\
\hline & $\begin{array}{c}\mathrm{Ba} \\
(10)\end{array}$ & $\begin{array}{r}\mathrm{Be} \\
(1)\end{array}$ & $\begin{array}{c}\mathrm{Bi} \\
(10)\end{array}$ & $\begin{array}{c}\mathrm{Cd} \\
(20)\end{array}$ & $\begin{array}{l}\text { Co } \\
\left\{\begin{array}{l}10) \\
(20)\end{array}\right.\end{array}$ & $\begin{array}{c}\mathrm{Cr} \\
(10)\end{array}$ & $\begin{array}{c}\mathrm{Cu} \\
(10)\end{array}$ & $\begin{array}{c}\mathrm{La} \\
(50) \\
\mathrm{l}_{(100)}\end{array}$ & $\begin{array}{l}\text { Mo } \\
\text { (5) }\end{array}$ & $\begin{array}{c}\mathrm{Nb} \\
(50)\end{array}$ & $\begin{array}{c}\mathrm{Ni} \\
(10)\end{array}$ & $\begin{array}{c}\mathrm{Pb} \\
(20)\end{array}$ \\
\hline $5 S$ & 700 & $L$ & $\mathrm{~N}$ & $\mathrm{~N}$ & $\mathrm{~N}$ & 10 & 500 & $\mathrm{~N}$ & $\mathrm{~N}$ & $\mathrm{~N}$ & $\mathrm{~N}$ & $\mathrm{~L}$ \\
\hline $8 S$ & 5,000 & 2 & $\mathrm{~N}$ & $\mathrm{~N}$ & $\mathrm{~N}$ & 70 & 10 & 50 & $\mathrm{~N}$ & $\mathrm{~L}$ & 10 & 150 \\
\hline 9S & 1,000 & 5 & $\mathrm{~N}$ & $\mathrm{~N}$ & $\mathrm{~L}$ & 20 & $\mathrm{~L}$ & 50 & $\mathrm{~N}$ & $L$ & 20 & 20 \\
\hline $10 \mathrm{~S}$ & $>10,000$ & 3 & $\mathrm{~N}$ & $\mathrm{~N}$ & L & 20 & $\mathrm{~L}$ & 50 & $\mathrm{~N}$ & $\mathrm{~L}$ & 10 & $\mathrm{~L}$ \\
\hline
\end{tabular}

\begin{tabular}{|c|c|c|c|c|c|c|c|c|c|c|c|}
\hline \multirow{3}{*}{$\begin{array}{l}\text { Locality } \\
\text { No. } \\
\text { (fig. 2) }\end{array}$} & \multicolumn{11}{|c|}{ Analyses, in parts per million } \\
\hline & \multicolumn{10}{|c|}{ Spectrographic } & \multirow{2}{*}{ 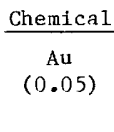 } \\
\hline & $\begin{array}{c}\mathrm{Sb} \\
(200)\end{array}$ & $\begin{array}{c}\mathrm{Sc} \\
(10)\end{array}$ & $\begin{array}{c}\text { Sn } \\
(20)\end{array}$ & $\begin{array}{l}\mathrm{Sr} \\
(200)\end{array}$ & $\begin{array}{l}V \\
(10)\end{array}$ & $\begin{array}{c}W \\
100) \\
(50)\end{array}$ & $\begin{array}{l}\mathrm{Y} \\
(20)\end{array}$ & $\underset{(500)}{\mathrm{Zn}}$ & $\begin{array}{c}\mathrm{Zr} \\
(20)\end{array}$ & $\begin{array}{l}\text { Th } \\
(200)\end{array}$ & \\
\hline $5 \mathrm{~s}$ & $\mathrm{~N}$ & $\mathrm{~L}$ & $\mathrm{~N}$ & 200 & 100 & $\mathrm{~N}$ & 50 & $\mathrm{~N}$ & 300 & $\mathrm{~N}$ & $\mathrm{~N}$ \\
\hline 85 & $\mathrm{~N}$ & $\mathrm{~L}$ & $\mathrm{~N}$ & $\mathrm{~N}$ & 70 & $\mathrm{~N}$ & 30 & $\mathrm{~N}$ & 2000 & $\mathrm{~N}$ & 3.94 \\
\hline $9 \mathrm{~S}$ & $\mathrm{~N}$ & 10 & $\mathrm{~N}$ & $\mathrm{~N}$ & 70 & $\mathrm{~N}$ & 70 & $\mathrm{~N}$ & 500 & $\mathrm{~N}$ & $\mathrm{~L}$ \\
\hline $10 \mathrm{~S}$ & $\mathrm{~N}$ & 10 & $\mathrm{~N}$ & $\mathrm{~N}$ & 50 & $\mathrm{~N}$ & 70 & $\mathrm{~N}$ & 700 & $\mathrm{~N}$ & $\mathrm{~L}$ \\
\hline
\end{tabular}

${ }_{\text {Limit }}$ of determination applies only to sample locality 5 .

associated with low-density silicic volcanic rocksprincipally rhyolite and latite-shown on the regional geologic map of figure 4. The northward and northwestward divergence of the eastern and western lows, respectively, from the terrane of volcanic rocks is sharply defined by a two-pronged occurrence of discontinuous patches of these extrusives. Volcanic rocks extend into the southern part of the eastern low, as shown on figure 5 , but end about $1 \mathrm{mi}$ south of the western low of the figure. By extrapolation of these lows northward and northwestward from these limits of exposed rocks, we tentatively infer that in the map area of figure 5 both gravity lows are underlain by concealed, low-density, intrusive rocks similar in composition to the volcanic rocks. Thus, the western gravity low is inferred to be caused by a combination of these concealed intrusives and adjacent monzogranite; the eastern gravity low is inferred to be caused by a combination of the hidden intrusives and low-density basin fill. The wilderness study area itself is located on a locally flattened part of the eastern flank of the western gravity low, suggesting that Belt Supergroup strata underlying the study area abut, or are very close to, the inferred concealed intrusive rocks to the west.

\section{Magnetic Anomaly Interpretation}

The aeromagnetic anomaly map (fig. 6) shows four notable features: (1) part of a magnetic high in the northeast corner of the map; (2) part of a magnetic high in the northwest corner of the map; (3) a conspicuous magnetic high in the eastern half of the map, here termed 


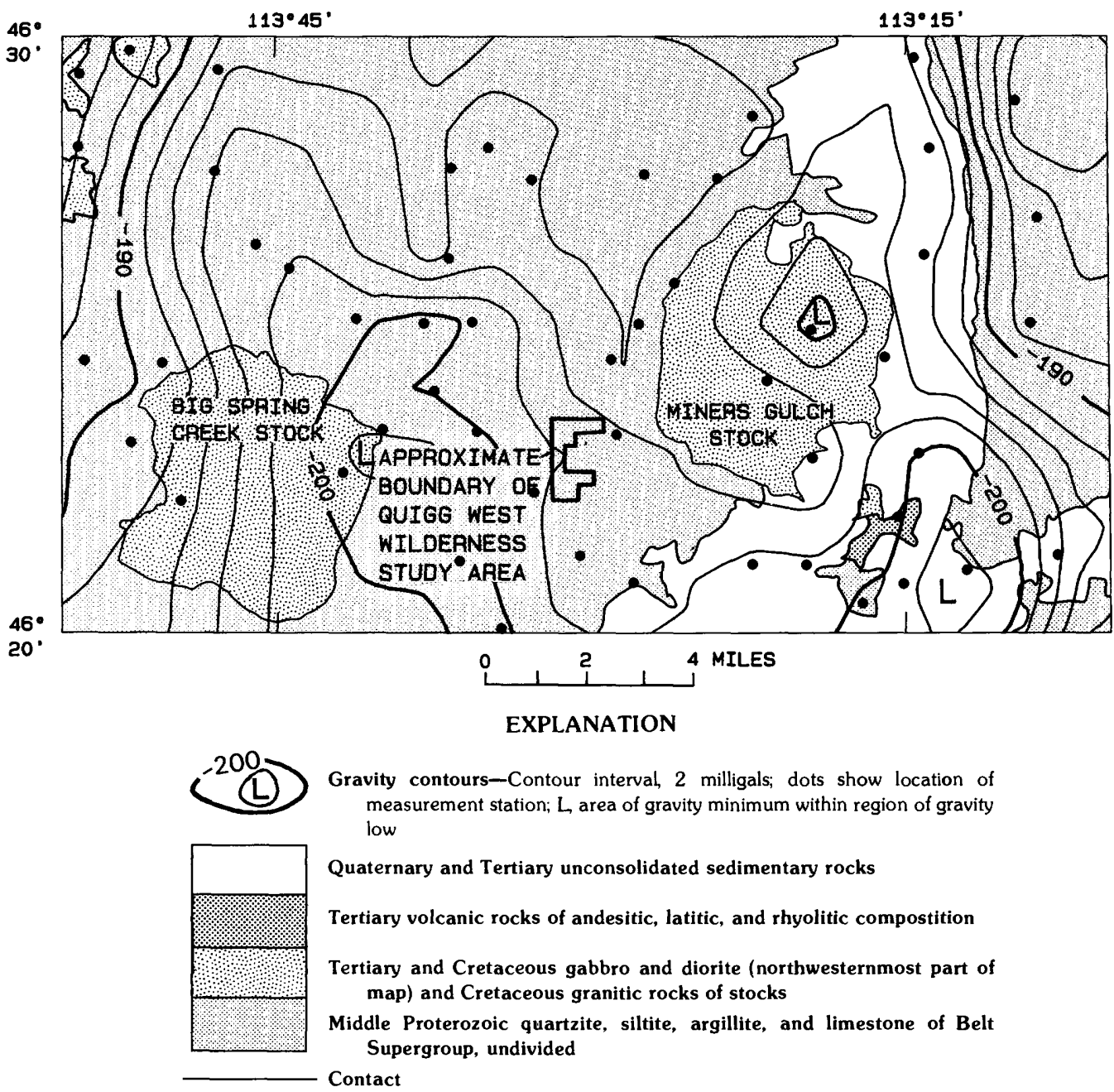

Figure 5. Terrain-corrected Bouguer gravity anomaly map and generalized geology in the vicinity of the Quigg West Wilderness Study Area, Montana.

"the eastern magnetic high;" and (4) an irregular magnetic high in the western half of the map, here termed "the western magnetic high." The wilderness study area is situated at the southwestern extremity of the eastern magnetic high. The high in the northeastern corner is a blunt nose that represents the southwestern subsurface extent of granodiorite of the Henderson Creek stock, which crops out about 4 mi east of the map area of figure 6 . The high in the northwestern corner is associated with discontinuous exposures of gabbro, microgabbro, and diorite, and probably coincides with subsurface bodies of these compositions. This high indicates that the mafic igneous rocks extend continuously beneath Belt strata in a zone from the map area to the southern margin of the the Welcome Creek stock, which is exposed 3 mi north of the area of figure 6 .

The highest part of the conspicuous eastern magnetic high, which covers the western two-thirds of the Miners Gulch stock, clearly is associated with strongly magnetic granodiorite of this part of the stock. The major indentation of the contour lines over much of the eastern third of the stock indicates the existence of less strongly magnetic rocks. One explanation for this occurrence of weakly magnetized material is that it represents a less magnetic phase of granodiorite. Another explanation, based on observations made $50 \mathrm{mi}$ to the east (Hanna, 1969), is that the granodiorite is both hydrothermally altered and intruded at depth by material of felsic composition. As stated in the discussion of gravity anomalies, field work in this area (Loen and others, in press) has delineated a porphyritic granodiorite body that is younger than the main phase of the Miners Gulch stock and has an associated zone of alteration.

The western magnetic high is associated with the Big Spring Creek stock. The irregular magnetic high appears to be related to partly exposed, but mostly buried, hornblende-biotite granodiorite that C.A. Wallace (oral commun., 1987) found to rim the large exposure of monzogranite on the western and southern margins of the stock. This partial rimming of monzo- 


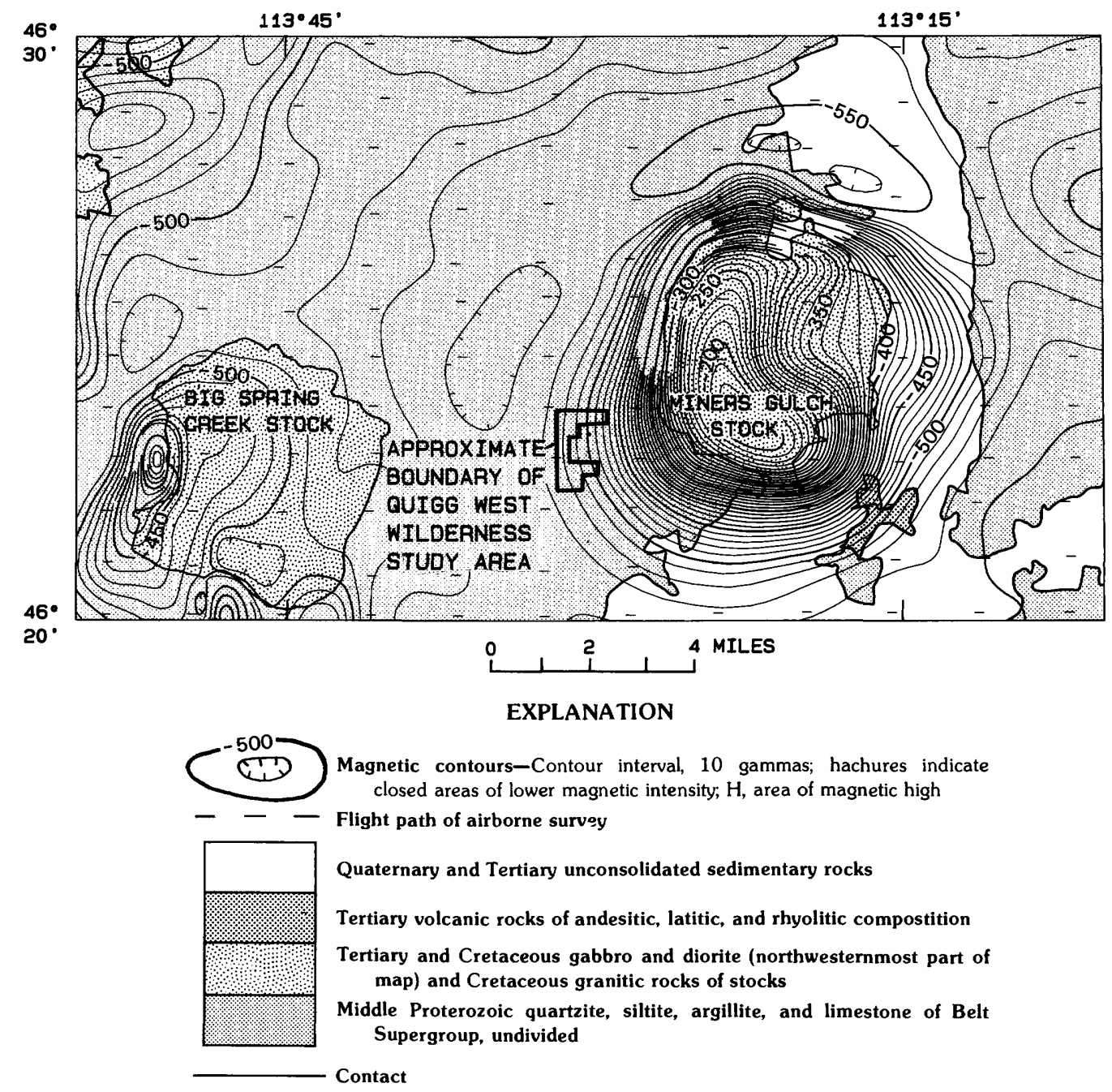

Figure 6. Aeromagnetic anomalies and generalized geology in the vicinity of the Quigg West Wilderness Study Area.

granite by granodiorite is mirrored on a much grander scale in the strongly zoned $600-\mathrm{mi}^{2}$ Sapphire batholith (Wallace and others, 1982) $12 \mathrm{mi}$ to the south, where strongly magnetic granodiorite and monzogranite completely encircle weakly magnetic granodiorite and monzogranite. Two peaks of high amplitude and short wavelength on the western magnetic high of the Big Spring Creek stock (fig. 6) suggest that minor amounts of gabbro may occur with the granodiorite in the subsurface.

Relative to the eastern magnetic high, Belt Supergroup strata beneath the wilderness study area lie about $1 \mathrm{mi}$ west of the granodiorite in the subsurface of the Miners Gulch stock. The region extending west from the study area, to the western magnetic high, is underlain by weakly magnetic to nonmagnetic rocks; such rocks could be Belt strata, or granitic intrusive rocks, such as those inferred from the gravity anomaly data.

\section{Mineral Resources}

\section{Gold and Molybdenum}

Two deposit models are used in an evaluation of the mineral resource potential for lode gold in the wilderness study area; gold in placers also is assessed. (1) In the section entitled "Gold associated with granitic intrusive rocks," characteristics of mineralized quartz veins in granitic and country rocks adjacent to the Miners Gulch stock are described and compared with those of the wilderness study area. The two areas have similar geologic settings. (2) A bipartite model of a stockwork porphyry molybdenum system also is compared with mineralized rocks of the wilderness study area. (a) In the section entitled "Gold in interior part of porphyry molybdenum deposit model," gold-bearing quartz veins within the Miners Gulch stock are described. The veins are part of a mineralized area that has several charac- 
teristics in common with a low-fluorine porphyry molybdenum deposit (Loen and others, in press). (b) In the section entitled "Gold in peripheral zone of porphyry molybdenum deposit model," silver-copper-gold mineralization that appears to be 2-3 mi distant from granitic rocks (Waisman, 1985) is described.

Gold associated with granitic intrusive rocks. - The model used for gold associated with an igneous intrusive is based on rocks in Jimmy Lee Gulch, located about $3 \mathrm{mi}$ east-southeast of the wilderness study area (fig. 1). The intrusive at Jimmy Lee Gulch (labeled Kgdm on figure 4) lies about $3 \mathrm{mi}$ southeast of the southeast corner of the Miners Gulch stock. The following characteristics of the model are from data of J.E. Elliott (written commun., 1987), and geophysical data from the present report. (1) Gold and associated elements occur in quartz veins, commonly about $1 \mathrm{ft}$ thick, which are (2) in shear zones, breccia zones, or small faults that cut both the granite and the adjacent country rock of the Belt Supergroup. (3) The veins are spatially, and presumably genetically, related to an intrusive, a porphyritic quartz monzonite (classification system of the International Union of Geological Scientists, Streckeisen, 1973) that contains more potassium feldspar and less quartz than the biotitehornblende granodiorite of the Miners Gulch stock. The Jimmy Lee Gulch intrusive is compositionally distinct from the Miners Gulch stock. (4) The Jimmy Lee Gulch intrusive is small and lacks significant density contrast with the surrounding rocks; hence, it is not discernible at the scale and contour interval of the gravity map (fig. 5). (5) The intrusive lies about $3 \mathrm{mi}$ from the Miners Gulch stock and (6) lies outside the closely spaced magnetic contour lines that define the steep gradient, and nearly vertical contact, at the southeast margin of the stock (fig. 6 ). The quartz monzonite intrusive does not display the magnetic properties of the Miners Gulch stock. (7) Mineralized veins are chiefly in the country rock, and (8) contain anomalous amounts of several elements. The range of values are shown in parentheses, as follows, where $L=$ less than limit of detection and $N=$ no detection (the limits of detection for each element are shown in table 1): gold (low to $16 \mathrm{ppm}$ ), silver (not detected to $2 \mathrm{ppm}$ ), molybdenum (not detected to 50 $\mathrm{ppm}$ ), arsenic (not detected to $450 \mathrm{ppm}$ ), and barium (150 to greater than 5,000 ppm). The highest values were obtained from samples of dump materials. (9) The veins and adjacent rock show argillic alteration and silicification. (10) Barite is a common gangue mineral in the gold-bearing quartz veins.

The mineralized area of the Sheep Gulch anomaly of the wilderness study area (fig. 2) has many features in common with those of the Jimmy Lee Gulch area, as shown by the following point by point comparison. (1) The suite of anomalous elements in the Sheep Gulch anomaly is like that at Jimmy Lee Gulch, except that the
Sheep Gulch suite includes bismuth and copper in addition to gold, molybdenum, arsenic, and barium. Silver is present at Sheep Gulch, but not in anomalous amounts as it is at Jimmy Lee Gulch. Anomalous elements common to both areas have a similar range of values (table 1). Three of the four rock samples (1R-4R, table 1) analyzed from the Sheep Gulch anomaly yielded gold, with values ranging from 0.15 to $0.65 \mathrm{ppm}$; gold was found in one stream-sediment sample (4S, table 2$)$ and was detected (but was not measurable) in a concentrate sample (9S, table 3). USBM assays of samples from the one prospect (1P) (fig. 2) in the area yielded gold quantities ranging from 0.004 to $1.244 \mathrm{oz} /$ ton. (2) Mineralized quartz veins at Sheep Gulch are in small fault zones, as they are at Jimmy Lee Gulch. (3) No granitic intrusive rocks are exposed within or immediately adjacent to the study area, as they are in the model area. But (4) on the basis of gravity data, it is reasonable to infer that granitic rocks may lie concealed near or beneath the Sheep Gulch anomaly. The study area lies along the eastern part of the western gravity low (fig. 5). As discussed previously, the terrane of Belt Supergroup strata immediately west of the study area may have been intruded by hidden silicic rocks of low density and weak magnetization; or, less likely, by moderately dense, weakly magnetic, monzogranite in a concealed eastward extension of the Big Spring Creek stock. (5) The Sheep Gulch anomaly lies about $2 \mathrm{mi}$ from the margin of the Miners Gulch stock, similar to the 3-mi distance of the intrusive at Jimmy Lee Gulch. (6) The magnetic map (fig. 5) shows that the Sheep Gulch anomaly is not underlain by biotite-hornblende granodiorite of the stock. Closely spaced magnetic contours indicate that the southwest margin of the stock is nearly vertical, the same as at the southeast margin near Jimmy Lee Gulch. (7) The mineralized quartz veins are in country rock, in contrast to their presence in both granitic and country rocks at Jimmy Lee Gulch. (9) The alteration zone of the Sheep Gulch area is of the argillic to sericitic stage. In contrast to the model area, the zone of alteration extends well beyond individual quartz veins, affecting country rock over thousands of square feet. This contrast may indicate that the north-south fault (fig. 2) of the wilderness study area provided a much better conduit for mineralizing fluids than did the small faults of Jimmy Lee Gulch.

Resource potential.-The mineral resource potential for gold and associated molybdenum in quartz veins (and adjacent country rock) deposited under the conditions of the granitic intrusive rocks model in the area of the Sheep Gulch anomaly in the southern part of the study area is rated as moderate, with a certainty level of $\mathrm{C}$ : the available information gives a good indication of the level of mineral resource potential. The mineral resource potential for gold and associated molybdenum 
in quartz veins in the remainder of the wilderness study area is rated as low, with a certainty level of $\mathrm{C}$.

Gold in interior part of porphyry molybdenum deposit model. - The mineralized area of the granodiorite plug that intrudes the Miners Gulch stock has the following characteristics, summarized from Loen and others (in press) for an area associated with a porphyritic granodiorite plug in the central part of the eastern third of the stock (fig. 4). Most of the characteristics are typical of low-fluorine, or calc-alkaline, stockwork porphyry molybdenum systems (Westra and Keith, 1981; Theodore, 1982, 1986). (1) The mineralized area is centered about a porphyritic granodiorite plug that is about $0.5 \mathrm{mi}$ in diameter, nearly cylindrical in plan view, and probably is steep sided. (2) Granodiorite of the plug lacks mafic minerals, in contrast to that of the hornblende-biotite granodiorite of the Miners Gulch stock. (3) The mineralized rock occurs in a stockwork of veins and fractures in the plug and surrounding rocks, and probably represents multiple stages of intrusion, fracturing, and mineralization. (4) A zone of pervasive propylitic, argillic, and sericitic alteration characterizes the plug, adjacent rocks, and related dikes of porphyritic granodiorite and dacite that locally cut the plug and adjacent rocks. (5) Anomalous concentrations of molybdenum are present in the hydrothermally altered plug and adjacent rocks, stockwork veins, and dikes that cut the plug and adjacent altered rocks. The geochemical signature also includes anomalous amounts of antimony, gold, arsenic, tungsten, and barium. Antimony, arsenic, and the highest gold values each define semicircular halos at a radius of about $1.5 \mathrm{mi}$ from the center of the plug. The highest barium values are concentrated within the molybdenum anomaly.

In addition to the preceding data that generally are typical of low-fluorine porphyry molybdenum systems, (6) the area of the porphyritic granodiorite plug is marked by a pronounced westward indentation in the bold, positive magnetic anomaly pattern of the Miners Gulch stock (fig. 6), reflecting (a) the absence of magnetic minerals from the granodiorite plug and (b) hydrothermal alteration of the magnetic minerals in the older granodiorite of this part of the stock. (7) The north-trending eastern gravity low overlies the eastern third of the Miners Gulch stock (fig. 5), reflecting (a) the slightly less dense rocks of the plug; (b) the hydrothermally altered rocks of the stock; and perhaps (c) other, concealed, felsic igneous rocks as well.

In the wilderness study area, the Sheep Gulch anomaly has several characteristics (items 1-4 that follow) that are the same or similar to those of the mineralized area in and adjacent to the granodiorite plug of the Miners Gulch stock. None of these four characteristics is considered definitive for determining if minerals of the study area are related to porphyry molybdenum mineralization. Items 5 and 6 that follow, however, suggest that the Sheep Gulch anomaly does not represent mineralized rock of a porphyry molybdenum system. (1) The Sheep Gulch anomaly contains a suite of elements similar to that present in the area of the granodiorite plug that intruded the Miners Gulch stock and in about the same range of values (table 1). Tungsten, however, was not detected in the samples from the Sheep Gulch anomaly, but it is present in the area of the plug. Anomalous values of molybdenum in goldbearing quartz veins are similar to those reported by Loen and others (in press) from the area of the Miners Gulch stock. But molybdenum also is known to occur in quartz veins in the general region, where no porphyry molybdenum deposits are known to exist, as shown by the data of Loen and others (in press, and unpub. data) and by Campbell and others (1982a, and unpub. data). (2) The quartz veins east of the plug are in granodiorite of the Miners Gulch stock, but in quartzite of the Belt Supergroup at Sheep Gulch. Both the granodiorite of the stock and the quartzite are country rock and are independent of a porphyry molybdenum system. (3) The Sheep Gulch anomaly also differs from that of the mineralized halo of the granodiorite plug in that gold is present in strata of the Belt Supergroup as well as in the quartz veins. This is not a definitive criterion for or against a plug existing beneath the wilderness study area because a halo of mineralized sedimentary rock at one time could have existed over the granodiorite plug of the Miners Gulch stock, as well as lateral to it as is presently true. (4) Alteration in the vein systems in the two areas east of the plug is sericitic, and occurs mainly in veins and for a few feet into adjacent country rock. This alteration contrasts with the widespread alteration of country rock at the Sheep Gulch anomaly where, as noted earlier, a large fault may have served as a conduit for mineralizing fluids.

Features that characterize the exposed, pervasively altered zone of the probable low-fluorine porphyry molybdenum system in the east-central part of the Miners Gulch stock are not found in the wilderness study area. (5) No granodiorite plug is exposed in or near the wilderness study area, and (6) gravity data indicate that a plug is not likely to be concealed beneath the study area. The area of the granodiorite plug in the Miners Gulch stock is coincident with the gravity minimum of the eastern gravity low (fig. 5), indicating a mass of lowdensity altered rock (both exposed and concealed). The pattern of the western gravity low is permissive of altered rocks beneath the Sheep Gulch anomaly, but the study area lies about 3 mi east of the gravity minimum of the western gravity low. Hence, mineralized rocks that constitute the Sheep Gulch anomaly probably were not formed within a porphyry molybdenum system. 
Resource potential.-The mineral resource potential for gold and molybdenum deposited in the interior part of a porphyry molybdenum system in the Quigg West Wilderness Study Area is rated as low, with a certainty level of $\mathrm{C}$.

Gold in peripheral zone of porphyry molybdenum deposit model. - This part of the model is based on data of Waisman (1985) and regional mineral resource studies of J.E. Elliott (written and oral communs., 1987, and unpub. data). Elliott's studies indicate that the John Long Mountains several miles east of the study area (fig. 1) contain mines, prospects, and mineral occurrences characterized by quartz veins, or vein systems, that are laterally extensive and generally concordant to bedding of the country rocks. The deposits probably are associated with the peripheral zones of porphyry molybdenum systems. The deposits are distal to exposed granitic intrusives, or to inferred (concealed) granitic intrusives, and provide the characteristics for the distal features of the porphyry molybdenum model.

The silver-copper-gold veins of the John Long Mountains have been important mainly as silver producers but also have yielded gold and copper and minor amounts of lead and zinc. They also typically contain anomalous concentrations of antimony, arsenic, bismuth, barium and, locally tungsten, molybdenum, and tin. The most important mine of this type is the Black Pine, located about $12 \mathrm{mi}$ northeast of the study area (fig. 1), which produces silver-copper-lead-zinc ore. Since 1974, about 1 million tons of ore have been mined (Waisman, 1985). Another important deposit of this type is the Silver King mine, located about $7 \mathrm{mi}$ southeast of the study area. This mine produced approximately 2,650 tons of gold-silver ore during 1976-80 (J.E. Elliott, unpub. data). The principal ore minerals are tetrahedrite, chalcopyrite, sphalerite, and galena. These occur in a gangue of quartz that contains abundant pyrite and minor huebnerite, a manganese-tungsten mineral (Waisman, 1985; Volin and others, 1952; Emmons and Calkins, 1913; and J.E. Elliott, written commun., 1987).

The following features of these mineral deposits serve as criteria that characterize mineralized rock in distal vein deposits of the porphyry molybdenum model. The data are from Waisman (1985), Campbell and others (1982a), and J.E. Elliott (unpub. data). (1) The deposits are in the peripheral zone of a known or suspected porphyry molybdenum system, and (2) are 2-3 mi distant from granitic intrusive rocks. (3) The deposits are in a favorable structural environment, which at the Black Pine mine is fractured rock related to a major thrust fault. (4) The deposits are hosted by a thick, brittle sequence of rocks, which in the John Long Mountains are strata of the Belt Supergroup. (5) Anomalous concentrations of tin, tungsten, and (or) molybdenum are present in rock, stream-sediment, and (or) concentrate samples, indicating the existence of a porphyry molybdenum system. Mineralized quartz veins like those of the Black Pine mine yield anomalous concentrations of the following suite of elements: silver, copper, gold, bismuth, arsenic, antimony, barium, lead, zinc, and (or) tungsten.

Resource potential.-The mineral resource potential for silver, copper, and gold in quartz veins formed in the peripheral zone of a porphyry molybdenum system within the wilderness study area is rated as low, with a certainty level of $\mathrm{C}$. The wilderness study area lacks several elements that are present in anomalous concentrations in the element suite indicative of the peripheral part of a porphyry molybdenum system. Further, silver values reported from mineral deposits of this type are several times higher than those observed in rocks of the wilderness study area.

Gold in placer deposits. - Strata in which gold placer deposits may exist in the wilderness study area include some of the same types of deposits as those found in the extensively placer-mined Miners Gulch area 3-6 mi to the east. The Miners Gulch placer deposits, recently studied by Loen and others (in press), are described briefly and used as a comparative model for deposits in the wilderness study area.

Placers in the Miners Gulch area overlie the eastern part of the Miners Gulch stock. They occur in alluvium, colluvium, lower terrace deposits, and upper terrace deposits (Loen and others, in press). The alluvial placers were the most widespread, the most intensely mined, and the most productive. They are restricted to active stream channels and contain rounded quartzite clasts recycled from the terrace gravels. Terrace deposits were not mined, although test pits had been dug into them in an apparent evaluation effort. Loen and others (in press) speculated that the terrace gravels were not mined because the grade of gold was too low, the clay content was too high, and (or) a water supply was not available. They sampled a trench cut into the terrace gravels but found only a "negligible amount of gold."

The wilderness study area does not contain deposits correlative with the lower terrace deposits of the Miners Gulch area. Colluvium in the study area is present in local patches but is only a veneer. Gold in these two types of deposits is not considered further.

Terrace deposits of the Quigg West Wilderness Study Area overlie parts of two ridges (fig. 2) and probably are remnants of stream-laid deposits. The gravels lie at about the same elevation as the "upper terrace" deposits of Loen and others (in press). One test pit (loc. 5S, fig. 2) was dug to sample the terrace gravels of the study area and the sample from it did not yield detectable amounts of gold. 
Alluvial deposits of active streams in the wilderness study area yielded measurable amounts of gold in only one stream-sediment sample (4S, table 2, $0.10 \mathrm{ppm}$ ), and no concentrate samples, within or immediately adjacent to the wilderness study area. The sample from locality $4 \mathrm{~S}$ (fig. 2) is from within the Sheep Gulch anomaly and was collected downslope from an area of mineralized quartz veins. The gold could have come from the veins, or from the terrace gravels that cap the ridges to the north and south, assuming the terrace gravels contain gold. Sheep Gulch contains only a minor amount of alluvial material deposited by the presently active stream.

About $1 \mathrm{mi}$ southeast of the wilderness study area, in Windlass Gulch, a heavy-mineral concentrate sample from locality $8 \mathrm{~S}$ (fig. 2) yielded a gold value of $3.94 \mathrm{ppm}$ (table 3 ). The sample could reflect gold concentrated from one or more possible sources: (1) mineralized rock that is present in the Sheep Gulch anomaly in the wilderness study area; (2) the terrane east of Windlass Gulch; (3) terrace gravels that cap ridges adjacent to Windlass Gulch; or (4) veins within or adjacent to the Miners Gulch stock, part of which is drained by the stream in Windlass Gulch. The stream-sediment sample from locality 7S, 2 mi upstream from locality $8 S$ and near the edge of the stock (fig. 2), did not have detectable gold at the detection limit of $10 \mathrm{ppm}$ but was not analyzed by the more sensitive chemical method which has a detection limit of $0.07 \mathrm{ppm}$.

Resource potential. - The mineral resource potential for gold in placer deposits of the terrace gravels in the wilderness study area is rated as low, with a certainty level of B. A higher level of certainty would require that additional pits be dug to sample the terrace gravels. The gravels lie at about the same elevation as those of the Miners Gulch area, which apparently lack significant concentrations of gold. The mineral resource potential for gold in placer deposits of presently active streams within the wilderness study area is rated as low, with a certainty level of $\mathrm{C}$.

\section{Copper and Silver}

Strata-bound copper-silver deposits.-Copper-silver sulfide minerals in strata-bound deposits occur in three types of rocks in the Belt Supergroup of western Montana: green argillite, carbonate (limestone and dolomite) beds, and sandstone (Harrison, 1972, 1974). The first two types are discussed only briefly, due to a lack of outcrops of the host-rock types within the wilderness study area.

In the argillite type, minerals occur in green argillite in sequences where red and green argillite beds are closely associated (Harrison, 1972, 1974; Harrison and Reynolds, 1979). No strata of this association were seen in the study area, although there is a slight possiblility that such strata could be present, but unobserved. The carbonate-hosted copper-silver sulfide minerals occur in carbonate strata of the Helena Formation (Harrison, 1972, 1974) and in limestone to calcareous siltstone of the Middle Proterozoic Spokane Formation of the Ravalli Group of the Belt (Lange and Eby, 1981; Lange and Sherry, 1986; Lange and others, 1987). The Helena Formation crops out in the general region of the study area (in the southern part of the region shown on fig. 4), but no strata-bound copper-silver sulfide occurrences have been reported (Lidke and others, 1983; J.E. Elliott, oral commun., 1987); the Spokane Formation is not present near the study area.

In the sandstone-hosted strata-bound copper-silver sulfide deposits, ore minerals occur in fine- to mediumgrained beds of quartzite, which commonly are crossbedded (Clark, 1971; Harrison, 1974; Hayes and Einaudi, 1987). Deposits of this type are known in prospects about 20-25 mi southeast of the study area (J.E. Elliott, oral commun., 1987), and rocks in the wilderness study area are possible host strata for similar deposits.

In a resource appraisal of the Wallace $1^{\circ} \times 2^{\circ}$ topographic quadrangle (northwest of Missoula), Montana and Idaho, Harrison and others (1986) presented several geochemical criteria that are useful in the assessment of potential for strata-bound coppersilver sulfide deposits. They found that stream-sediment samples in drainages near known strata-bound coppersilver sulfide occurrences show anomalous amounts of copper, with or without silver or lead. None, however, contains anomalous amounts of bismuth, molybdenum, antimony, or zinc. These criteria were utilized to aid in interpretation of the stream-sediment samples of the Quigg West Wilderness Study Area.

In the Quigg West Wilderness Study Area, streamsediment samples $2 \mathrm{~S}$ and $3 \mathrm{~S}$ from Capron Creek (fig. 2; table 2) contain anomalous amounts of copper (100 and $1,000 \mathrm{ppm}$, respectively), and $3 \mathrm{~S}$ shows silver and anomalous lead (70 ppm); bismith, molybdenum, antimony, and zinc were not detected in the spectrographic analyses of these samples. The two samples are from a sluggish stream, and some of the sampled material contained mud that gave off a hydrogen sulfide odor, thus indicating a reducing environment; such an environment might concentrate elements in greater amounts than would a nonreducing environment. However, the sample from locality $1 S$, upstream from $2 S$ and $3 S$, has the same characteristics but lacks the concentration of copper. Samples $2 \mathrm{~S}$ and 3S, therefore, are considered anomalous and permissive for strata-bound copper-silver deposits. Possible sources for the copper are considered as follows.

1. The anomalous copper values could reflect source terrane north of the study area. The samples are from a drainage that is divided upstream from sample locality $3 S$ (fig. 2). No sample was taken from the eastern 
fork, which extends about $0.5 \mathrm{mi}$ north of the study area boundary, because the drainage bottom was dry and covered by large blocks of talus. The western fork extends about $1.5 \mathrm{mi}$ upstream (north) from sample locality $2 \mathrm{~S}$, which is near the northern edge of the study area, but a sample from locality $1 \mathrm{~S}(0.4 \mathrm{mi}$ north of the boundary) did not show anomalous concentrations of copper or other elements. A source within the study area is possible.

2. Mineralized rock of the strata-bound variety typically occurs in layers that are commonly less than 25 $\mathrm{ft}$ thick, in some places only 1-2 ft thick, yet much of the bedrock in the Capron Creek drainage is covered by talus or by alluvium, making a bedrock source for the copper difficult to find. No mineralized rocks were found in outcrops in the vicinity of the copper-bearing stream sediments, but three rock samples (11R-13R; fig. 2, table 1) were collected from talus on the west side of the stream. The sample from locality $11 \mathrm{R}$ is hydrothermally altered quartzite that contained an anomalous amount of arsenic and minor amounts of zinc; the sample from locality 13R is barite (from the head of a talus cone) that contained no anomalous amounts of metallic elements other than barium; the sample from locality $12 \mathrm{R}$ shows a boxwork texture of quartz but no anomalous concentrations of elements were detected.

3. The only rock sample that contained an anomalous amount of copper $(150 \mathrm{ppm})$ is from locality 5R (fig. 2), from a thin zone of sheared, tan, mediumgrained quartzite. The locality is near a ridge crest, in the drainage of Sheep Gulch, but the shear zone may extend west into the Capron drainage as well. This sample could reflect mineralizing fluids associated with the Sheep Gulch anomaly, although stream-sediment (locality $4 \mathrm{~S}$, 9S; table 2) and concentrate (locality 9S, table 3) samples from Sheep Gulch do not show higher values of copper. Rock samples $1 \mathrm{R}$ and 2R from the Sheep Gulch anomaly show values of $50 \mathrm{ppm}$ for copper. Strata represented by rock samples from localities $16 \mathrm{R}$ and $17 \mathrm{R}$, from the upper reaches of Sheep Gulch, strike at a high angle to the drainage, and thus represent strata that are drained by the stream; the samples yielded low amounts of copper.

4. Rock samples from 2 to $3 \mathrm{mi}$ north-northwest to northwest of the wilderness study area contain anomalous values of silver (3.6-80 ppm), copper (19-470 ppm), lead (26-960 ppm), zinc (7-160 ppm), cadmium (1.75-70), antimony (10-350 ppm), and barium (70-3000 ppm) (samples QUI0513R, 515R, 519R, 520R of Campbell and others, 1982a). One sample, 513R, contained anomalous amounts of zinc and antimony, elements that Harrison and others (1986) indicate are absent from stream-sediments in areas of strata-bound copper-silver mineralized rock. The samples are (1) from near a 2-mi-long stream segment that cuts middle member of the Mount Shields Formation, (2) on strike with strata of the wilderness study area, and (3) probably from strata of a single thrust sheet (location of thrust fault locally is queried on fig. 2). In regard to the foregoing, a plausible proposition is that the correlative Mount Shields strata in the wilderness study area may contain strata-bound copper-silver mineralized rock. However, the sediment samples from the stream that drains the area of the four rock samples failed to reveal anomalous concentrations of any of the elements.

Resource potential.-The mineral resource potential for copper and silver resources in strata-bound deposits of the sandstone type in the wilderness study area is rated as moderate in the northwestern part of the study area, with a certainty level of B. A higher level of certainty would require additional analyses of rock and stream-sediment samples collected from within and adjacent to the study area. In addition, because of limited exposures on the hillsides, a soil-sampling survey also would be useful to aid in determining the source of the copper in the stream-sediment samples. The mineral resource potential for copper and silver resources in the remainder of the study area is rated as low, with a certainty level $\mathrm{C}$.

\section{Sapphires in Placer Deposits}

For about 100 years sapphires have been recovered from placer deposits about 6-8 mi south of the study area (Clabaugh, 1952; Ziehen, 1987). The placers are in alluvial deposits in an area underlain by Tertiary volcanic and sedimentary rocks (fig. 4), but no bedrock source has yet been found for the sapphires (J.E. Elliott, oral commun., 1987). (The bedrock sources for sapphires in central Montana, for example, are mafic dikes (Clabaugh, 1952) and, possibly, contact-metamorphic rocks in the roof zone of a granitic intrusive (Mertie and others, 1951).) No sapphires are known to have been recovered from terrace deposits or deposits of active streams in the Miners Gulch area northeast of the wilderness study area (J.S. Loen, oral commun., 1987). However, Tertiary(?) gravel deposits similar to those of the Miners Gulch area have yielded sapphires in the area of the Sapphire batholith (12 mi south of the study area) (U.S. Geological Survey, 1980).

Terrace deposits overlie parts of two ridges in the southern part of the Quigg West Wilderness Study Area (fig. 2) and are the same deposits discussed in the section of this report entitled "gold in placer deposits." At one time the two areas of terrace deposits probably formed part of a single sheet of stream-laid gravels. The one sample collected from terrace gravels (locality 5S, fig. 2) did not contain sapphires and no sapphires are known to have been recovered from the terrace gravels or 
alluvium. No bedrock source for sapphires, such as mafic dikes or contact-metamorphosed rocks in the roof zone of an intrusive, occurs in or adjacent to the study area.

Resource potential.-The mineral resource potential for sapphires in the terrace gravels of the wilderness study area is rated as low, with a certainty level of B. A higher level of certainty would require digging additional test pits to sample the terrace gravels, and examining of the heavy mineral suite in deposits of the present streams. The absence of sapphires from the extensively mined and prospected placer deposits of the Miners Gulch area argues for a low resource potential in the Quigg West Wilderness Study Area.

\section{Barite}

White coarsely crystalline barite occurs in veins in the eastern part of the Miners Gulch stock (Loen and others, in press) and that occurrence serves as a deposit model for comparison. The barite veins of the stock are commonly less than $3 \mathrm{ft}$ thick and occupy fault or breccia zones within the stock. Sulfide minerals were found in only one of the veins, but none of the veins has been mined for metallic minerals or for barite. The veins are widely distributed, and the map of Blaskowski and others (1983) shows that they also are widely separated.

The wilderness study area is close to the Miners Gulch stock and barite of the study area likely would have had the same origin as that reported by Loen and others (in press). Barite was found only in one place, however, in float of a talus cone in the northwestern corner of the study area. Barite of the talus was traced to the head of the talus cone, immediately outside the study area, but no bedrock source was found. A float sample from locality 13R (fig. 2) at the top of the talus cone was analyzed (table 1) and showed no anomalous concentration of metallic elements. Heavy-mineral concentrate sample $10 \mathrm{~S}$, about $1.5 \mathrm{mi}$ downstream from the talus cone (fig. 2), shows a barite value of greater than 10,000 ppm. The sample probably represents barite carried downstream from talus in the area of locality 13R.

Resource potential.-The mineral resource potential for barite in veins in the wilderness study area is rated as low, with a certainty level of $C$. No barite veins were found in the wilderness study area, although the barite float of locality $13 \mathrm{R}$ probably came from a source immediately outside the study area. The sample, like most of those in the Miners Gulch area to the east, contained no anomalous concentration of metallic elements.

\section{Energy Resources}

Uranium.-The uranium potential of the Butte $1^{\circ} \times 2^{\circ}$ topographic quadrangle (area shown on fig. 3 ), in which the wilderness study area occurs, was evaluated during the National Uranium Resource Evaluation (NURE) program. No samples were collected from the study area, but sediment samples collected from streams that drain nearby strata of the same formations as occur in the study area do not show anomalous concentrations of uranium (Broxton, 1980). As part of the NURE study, Van Eeckhout (1980) and Sartoris and others (1982) concluded that the region of the study area lies west of the areas of the Butte quadrangle that are considered favorable for uranium deposits.

Intrusive rocks in the vicinity of the study area were specifically rated as unfavorable for uranium. A goldplacer deposit about $7 \mathrm{mi}$ west of the study area, on the western side of the Big Spring Creek stock (fig. 4), reportedly contained grains of a uranium mineral (brannerite), but more than 100 analyzed samples of plutonic and Belt metasedimentary rocks from the placer area yielded no detectable uranium; radiometric traverses revealed no anomalous uranium concentrations (Sartoris and others, 1982, p. 27). On the east side of the Big Spring Creek stock, about $3 \mathrm{mi}$ southwest of the study area, a uranium occurrence was found in Belt rocks adjacent to a hydrothermal quartz vein, but rock analyses and radiometric traverses in the area revealed no anomalous concentrations (Sartoris and others, 1982, p. 27-28).

Resource potential.-The resource potential for uranium in the study area is rated as low, with a certainty level of B. Geochemical sampling and radiometric surveying within the wilderness study area would be necessary to achieve a higher level of certainty.

Geothermal energy.-No hot springs, or tufa deposits of former hot springs, occur within or adjacent to the wilderness study area, and, according to the studies of Robertson and others (1976), Muffler (1979), and Sonderegger and Bergantino (1981), no known geothermal resource area (KGRA) exists within the region. The study area is near two major igneous intrusives, and concealed intrusives could lie adjacent to (or under) it. Near-surface rocks of these intrusives have cooled and thus could not provide heat to ground water. Deeply buried parts of the intrusives possibly could retain heat, but water heated by contact with the rock would require a conduit, such as a fault zone, to reach shallow depths. Steep faults occur within and near the study area, but at present do not serve as conduits for hot water.

Resource potential.-The wilderness study area is rated as having low potential for geothermal resources, with a certainty level of $\mathbf{B}$. A higher level of certainty would require specific studies, such as heat-flow measurements, to better evaluate the potential for geothermal resources.

Oil and gas.-The wilderness study area lies at the southern limit of an area rated by Perry and others (1983a) as having zero potential for petroleum resources. 
The study area lies immediately west of a large tract of land assigned "a zero oil potential and, optimistically, a low to zero gas potential on the basis of the possibility of thermogenic gas in generally low-grade Precambrian metamorphic rocks . .." (Perry and others, 1983b). Several geologic factors are unfavorable for the occurrence of petroleum resources in the study area. After strata of the Belt Supergroup in the study area were thrust into their present position, they were heated to the greenschist facies of metamorphism during burial and intrusion of igneous rocks. The Miners Gulch stock lies only $1 \mathrm{mi}$ to the east of the study area and the Big Spring Creek stock $3 \mathrm{mi}$ to the west. In addition, the study area may be adjacent to, or underlain by concealed granitic rocks, based on gravity data.

Resource potential.-The wilderness study area is rated as having no resource potential for oil or gas, with a certainty level of $\mathrm{D}$ : available data clearly define the level of resource potential.

\section{REFERENCES CITED}

Blaskowski, M.J., Loen, J.S., and Elliott, J.E., 1983, Map showing geology and mineral deposits of the southwest part of the Alder Gulch quadrangle, Granite County, Montana: U.S. Geological Survey Open-File Report 83-414, scale 1:10,000.

Broxton, D.E., 1980, Uranium hydrogeochemical and stream sediment reconnaissance data release for the Butte NTMS quadrangle, Montana, including concentrations of forty-two additional elements: U.S. Department of Energy Open-File Report GJBX-129(80), 207 p.

Campbell, W.L., McDanal, S.K., and Hopkins, R.T., Jr., 1982a, Coordinates for and analytical values of 486 rock, 771 stream sediment and soil, and 784 panned-concentrate samples included in the Butte $1^{\circ} \times 2^{\circ}$ quadrangle between the latitudes of $46^{\circ} 00^{\prime} 00^{\prime \prime}$ and $46^{\circ} 30^{\prime} 00^{\prime \prime} \mathrm{N}$., and the longitudes of $113^{\circ} 30^{\prime} 00^{\prime \prime}$ and $114^{\circ} 00^{\prime} 00^{\prime \prime}$ W.: U.S. Geological Survey Open-File Report 82-617-F, 119 p.

1982b, Sample location and analytical data for samples collected and analyzed as of June 1,1982 , in the eight 30-minute divisions of the Butte $1^{\circ} \times 2^{\circ}$ CUSMAP quadrangle, Montana: U.S. Geological Survey Open-File Report 82-617-A, 8 p.

Capstick, D.O., 1987, Mineral resources of the Quigg West Wilderness Study Area, Granite County, Montana: U.S. Bureau of Mines Open-File Report MLA 69-87, 13 p.

Clabaugh, S.E., 1952, Corundum deposits of Montana: U.S. Geological Survey Bulletin 983, 100 p.

Clark, A.L., 1971, Stratabound copper sulfides in the Precambrian Belt Supergroup, northern Idaho and northwestern Montana, U.S.A.: Proceedings of International Mineralogical Association General Meeting, 7th International Association on the Genesis of Ore Deposits, Tokyo-Kyoto Meeting, 1970, p. 261-267.
Emmons, W.H., and Calkins, F.C., 1913, Geology and ore deposits of the Philipsburg quadrangle, Montana: U.S. Geological Survey Professional Paper 78, 271 p.

Goudarzi, G.H., 1984, Guide to preparation of mineral survey reports on public lands: U.S. Geological Survey OpenFile Report 84-787, 30 p.

Grimes, D.J., and Marranzino, A.P., 1968, Direct-current arc and alternating-current spark emission spectrographic field methods for the semiquantitative analysis of geologic materials: U.S. Geological Survey Circular 591, $6 \mathrm{p}$.

Hanna, W.F., 1969, Negative aeromagnetic anomalies over mineralized areas of the Boulder batholith, Montana: U.S. Geological Survey Professional Paper 650-D, p. D159-D167.

Harrison, J.E., 1972, Precambrian Belt basin of northwestern United States: its geometry, sedimentation, and copper occurrences: Geological Society of America Bulletin, v. 83 , p. $1215-1240$.

1974, Copper mineralization in miogeosynclinal clastics of the Belt Supergroup, northwestern United States, in Bartholomew, Paul, ed., Gisements stratiformes et provinces cupriferes: Geological Society of Belgium, Liege, Belgium, p. 353-366.

Harrison, J.E., Domenico, J.A., and Leach, D.L., 1986, Resource appraisal map for stratabound copper-silver deposits in the Wallace $1^{\circ} \times 2^{\circ}$ quadrangle, Montana and Idaho: U.S. Geological Survey Miscellaneous Investigations Series Map I-1509-F, scale 1:250,000, text.

Harrison, J.E., and Reynolds, M.W., 1979, Preliminary geology of the Blacktail Mountain drilling site, Flathead County, Montana: U.S. Geological Survey Open-File Report 79-938, 36 p.

Hassemer, J.H., 1984, Principal facts, base station descriptions, and plots for gravity stations on and near the Butte $1^{\circ} \times 2^{\circ}$ quadrangle, Montana: Available from National Technical Information Service, U.S. Department of Commerce, Springfield, VA, as report NTIS-PB168103, $77 \mathrm{p}$.

Hassemer, J.H., and Hanna, W.F., 1982, Slides showing preliminary mosaic magnetic and complete Bouguer gravity anomaly maps of the Butte $1^{\circ} \times 2^{\circ}$ quadrangle, Montana: U.S. Geological Survey Open-File Report 82-603, two 35-mm slides, 4 p. text.

Hassemer, J.H., and Lidke, D.J., 1986, Physical properties of rock samples from the Butte $1^{\circ} \times 2^{\circ}$ quadrangle, Montana: U.S. Geological Survey Open-File Report $86-435,18 \mathrm{p}$.

Hayes, T.S., and Einaudi, M.T., 1987, Genesis of the Spar Lake strata-bound copper-silver deposit, Montana; Part I. Controls inherited from sedimentation and pre-ore diagenesis: Economic Geology, v. 81, p. 1899-1931.

Lange, I.M., and Eby, D.E., 1981, Stratabound copper-silverbearing oolitic deposits in the Belt Supergroup of Montana: Economic Geology, v. 76, p. 933-936.

Lange, I.M., Moore, J.N., and Krause, H.R., 1987, Diagenesis and copper mineralization in carbonates in the Spokane Formation, Belt Supergroup, at Wolf Creek, Montana: Economic Geology, v. 82, p. 1334-1347. 
Lange, I.M., and Sherry, R.A., 1986, Nonmassive sulfide deposits in the Late Precambrian Belt Supergroup of western Montana, in Roberts, S.M., ed., Belt Supergroup, a guide to Proterozoic rocks in western Montana and adjacent areas: Montana Bureau of Mines and Geology Special Paper 94, p. 269-278.

Lidke, D.J., Wallace, C.A., Antweiler, W.L., Campbell, W.L., Hassemer, J.H., Hanna, W.F., and Close, T.J., 1983, Mineral resource potential of the Welcome Creek Wilderness, Granite County, Montana: U.S. Geological Survey Miscellaneous Field Studies Map MF-1620-A, scale 1:50,000, text.

Lidke, D.J., Wallace, C.A., and Obradovich, J.D., 1987, Structural features and constraints on age of emplacement of the Sapphire thrust plate, west-central Montana: Geological Society of America Abstracts with Programs 1987, v. 19, no. 5, March 1987, p. 314.

Loen J.S., Blaskowski, M.J., and Elliott, J.E., in press, Gold placer deposits and a molybdenum anomaly in the Miners Gulch area, Granite County, Montana: U.S. Geological Survey Bulletin 1791.

Lyden, C.J., 1948, The gold placers of Montana: Montana Bureau of Mines and Geology Memoir 26, $151 \mathrm{p}$.

Mertie, J.B., Jr., Fischer, R.P., and Hobbs, S.W., 1951, Geology of the Canyon Ferry quadrangle, Montana: U.S. Geological Survey Bulletin 972, 97 p.

Muffler, L.P.J., editor, 1979, Assessment of geothermal resources of the United States: U.S. Geological Survey Circular 790, 163 p.

Perry, W.J., Jr., Rice, D.D., and Maughan, E.K., 1983a, Petroleum potential of wilderness lands, Montana: U.S. Geological Survey Miscellaneous Investigations Series Map I-1541, scale 1:1,000,000.

$1983 \mathrm{~b}$, Petroleum potential of wilderness lands in Montana, in Miller, B.M., ed., Petroleum potential of wilderness lands in the western United States: U.S. Geological Survey Circular 902-G, p. G1-G23.

Robertson, E.C., Fournier, R.O., and Strong, C.P., 1976, Hydrothermal activity in southwestern Montana: Proceedings, Second United Nations Symposium on the Development and Use of Geothermal Resources, San Francisco, California, USA, May 20-29, 1975, v. 1 p. 553-561.

Ruppel, E.T., Wallace, C.A., Schmidt, R.G., and Lopez, D.A., 1981, Preliminary interpretation of the thrust belt in southwest and west-central Montana and east central Idaho, in Tucker, T.E., ed., Field conference and symposium guidebook to southwest Montana: Montana Geological Guidebook, p. 139-159.

Sartoris, D.J., Gilmour, D.H., Salisbury, W.G., and McKee, C.J., 1982, National uranium resource evaluation, Butte quadrangle, Montana: U.S. Department of Energy Open-File Report PGJ/F-064(82), 43 p.

Sonderegger, J.L., and Bergantino, R.N., 1981, Geothermal resources of Montana: Montana Bureau of Mines and Geology Hydrogeologic Map HM-4, scale 1:1,000,000.

Streckeisen, A.L., 1973, Classification and nomenclature recommended by the IUGS subcommission on the systematics of igneous rocks: Geotimes, v. 18, p. 26-30.
Theodore, T.G., 1982, Preliminary model outline for fluorinedeficient porphyry molybdenum deposits, in Erickson R.L., ed., Characteristics of mineral deposit occurrences: U.S. Geological Survey Open-File Report 82-795.

1986, Descriptive model of porphyry Mo, low-F, in Cox, D.P., and Singer, D.A., eds., Mineral deposit models: U.S. Geological Survey Bulletin 1693, p. 120-122.

Thompson, C.E., Nakagawa, H.M., and Van Sickle, G.H., 1968, Rapid analysis for gold in geologic materials, in Geological Survey research: U.S. Geological Survey Professional Paper 600-B, p. B130-B132.

U.S. Bureau of Mines and U.S, Geological Survey, 1980, Principles of a resource/reserve classification for minerals: U.S. Geological Survey Circular 831, 5 p.

U.S. Geological Survey, 1980, Gold and sapphires in Tertiary gravels, Sapphire Range, Montana, in Geological Survey research: U.S. Geological Survey Professional Paper 1175 , p. 14.

1984, Aeromagnetic map of the Butte $1 \times 2^{\circ}$ quadrangle, Montana: U.S. Geological Survey Open-File Report 84-278, 6 sheets covering parts of area at scale 1:62,500 and one sheet covering entire area at scale 1:250,000.

Van Eeckhout, E.M., 1980, Utilizing the geochemical data from the national uranium resource evaluation (NURE) program-An evaluation of the Butte quadrangle, Montana: U.S. Department of Energy Open-File Report GJBX-58(81), 67 p.

Viets, J.G., Clark, J.R., and Campbell, W.L., 1984, A rapid, partial leach and organic separation for the sensitive determination of $\mathrm{Ag}, \mathrm{Bi}, \mathrm{Cd}, \mathrm{Co}, \mathrm{Mo}, \mathrm{Pb}, \mathrm{Sb}$, and $\mathrm{Zn}$ in surface geologic materials by flame atomic absorption: Journal of Geochemical Exploration, v. 20, p. 355-366.

Volin, M.E., Roby, R.N., and Cole, J.W., 1952, Investigation of the Combination silver-tungsten mine, Granite County, Montana: U.S. Bureau of Mines Report of Investigations 4914, 26 p.

Waisman, D.J., 1985, Geology and mineralization of the Black Pine mine, Granite County, Montana: Missoula, University of Montana, M.S. thesis, 66 p.

Wallace, C.A., Lidke, D.J., Elliott, J.E., Antweiler, J.S., Campbell, W.L., Hassemer, J.H., Hanna, W.F., Banister, D.P., and Close, T.J., 1984, Mineral resource potential map of the Sapphire Wilderness Study Area and contiguous Roadless Area, Granite and Ravalli Counties, Montana: U.S. Geological Survey Miscellaneous Field.Studies Map MF-1469-B, scale 1:50,000, text.

Wallace, C.A., Lidke, D.J., and Obradovich, J.D., 1982, Geologic map of the Sapphire wilderness and contiguous roadless areas, Granite and Ravalli Counties, Montana: U.S. Geological Survey Miscellaneous Field Studies Map MF-1469-A, scale 1:50,000, text.

Wallace, C.A., Lidke, D.J., Waters, M.R., and Obradovich, J.D., in press, Rocks and structure in the southern Sapphire Mountains, Granite and Ravalli Counties, western Montana: U.S. Geological Survey Bulletin 1824.

Wallace, C.A., Schmidt, R.G., Lidke, D.J., Waters M.R., Elliott, J.E., French, .B., Whipple, J.W., Zarske, S.E., Blaskowski, M.J., Heise, B.A., Yeoman, R.A., O’Neill, J.M., Lopez, D.A., Robinson, G.D., and Klepper, M.R., 1986, Preliminary geologic map of the Butte $1^{\circ} \times 2^{\circ}$ 
quadrangle, western Montana: U.S. Geological Survey Open-File Report 86-292, scale 1:250,000, text.

Wallace, C.A., Schmidt, R.G., Waters, M.R., Lidke, D.J., and French, A.B., 1981, Preliminary geologic map of parts of the Butte $1^{\circ} \times 2^{\circ}$ quadrangle, central Montana: U.S. Geological Survey Open-File Report 81-1030, scale 1:250,000.
Westra, Gerhard, and Keith, S.B., 1981, Classification and genesis of stockwork molybdenum deposits: Economic Geology, v. 76, p. 844-873.

Ziehen, L.G., 1987, The sapphire deposits of Montana, in Lawson, D.C., compiler, Directory of Montana mining enterprises for 1986: Montana Bureau of Mines and Geology Bulletin 126, p. 29-40. 


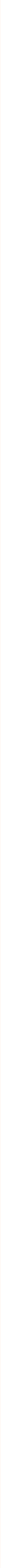


APPENDIX 


\section{DEFINITION OF LEVELS OF MINERAL RESOURCE POTENTIAL AND CERTAINTY OF ASSESSMENT}

\section{Definitions of Mineral Resource Potential}

LOW mineral resource potential is assigned to areas where geologic, geochemical, and geophysical characteristics define a geologic environment in which the existence of resources is unlikely. This broad category embraces areas with dispersed but insignificantly mineralized rock as well as areas with few or no indications of having been mineralized.

MODERATE mineral resource potential is assigned to areas where geologic, geochemical, and geophysical characteristics indicate a geologic environment favorable for resource occurrence, where interpretations of data indicate a reasonable likelihood of resource accumulation, and (or) where an application of mineral-deposit models indicates favorable ground for the specified type(s) of deposits.

HIGH mineral resource potential is assigned to areas where geologic, geochemical, and geophysical characteristics indicate a geologic environment favorable for resource occurrence, where interpretations of data indicate a high degree of likelihood for resource accumulation, where data support mineral-deposit models indicating presence of resources, and where evidence indicates that mineral concentration has taken place. Assignment of high resource potential to an area requires some positive knowledge that mineral-forming processes have been active in at least part of the area.

UNKNOWN mineral resource potential is assigned to areas where information is inadequate to assign low, moderate, or high levels of resource potential.

NO mineral resource potential is a category reserved for a specific type of resource in a well-defined area.

Levels of Certainty

\begin{tabular}{|c|c|c|c|}
\hline U/A & $\begin{array}{l}\text { H/B } \\
\text { HIGH POTENTIAL }\end{array}$ & $\begin{array}{l}\text { H/C } \\
\text { HIGH POTENTIAL }\end{array}$ & $\begin{array}{l}\text { H/D } \\
\text { HIGH POTENTIAL }\end{array}$ \\
\hline \multirow{3}{*}{$\begin{array}{l}\text { UNKNOWN } \\
\text { POTENTIAL }\end{array}$} & $\begin{array}{l}\text { M/B } \\
\text { MOOERATE POTENTIAL }\end{array}$ & $\begin{array}{l}\text { M/C } \\
\text { MODERATE POTENTIAL }\end{array}$ & $\begin{array}{l}\text { M/D } \\
\text { MODERATE POTENTIAL }\end{array}$ \\
\hline & $L / B$ & $L / C$ & $\begin{array}{l}\text { L/D } \\
\text { LOW POTENTIAL }\end{array}$ \\
\hline & $\begin{array}{c}\text { LOW } \\
\text { POTENTIAL }\end{array}$ & $\begin{array}{c}\text { LOW } \\
\text { POTENTIAL }\end{array}$ & $\begin{array}{l}\text { N/D } \\
\text { NO POTENTIAL. }\end{array}$ \\
\hline A & B & C & D \\
\hline
\end{tabular}

A. Available information is not adequate for determination of the level of mineral resource potential.

B. Available information suggests the level of mineral resource potential.

C. Available information gives a good indication of the level of mineral resource potential.

D. Available information clearly defines the level of mineral resource potential.

\section{Abstracted with minor modifications from:}

Taylor, R. B., and Steven, T. A., 1983, Definition of mineral resource potential: Economic Geology, v. 78 , no. 6, p. $1268-1270$.

Taylor, R. B., Stoneman, R. J., and Marsh, S. P., 1984, An assessment of the mineral resource potential of the San Isabel National Forest, south-central Colorado: U.S. Geological Survey Bulletin 1638, p. $40-42$.

Goudarzi, G. H., compiler, 1984, Guide to preparation of mineral survey reports on public lands: U.S. Geological Survey Open-File Report 84-0787, p. 7, 8. 


\section{RESOURCE/RESERVE CLASSIFICATION}

\begin{tabular}{|c|c|c|c|c|c|}
\hline & \multicolumn{3}{|c|}{ IDENTIFIED RESOURCES } & \multirow{2}{*}{\multicolumn{2}{|c|}{$\frac{\text { UNDISCOVERED RESOURCES }}{\text { Probability Range }}$}} \\
\hline & \multicolumn{2}{|c|}{ Demonstrated } & \multirow{2}{*}{ Inferred } & & \\
\hline & Measured & Indicated & & Hypothetical & Speculative \\
\hline ECONOMIC & & ves & Inferred Reserves & & \\
\hline $\begin{array}{l}\text { MARGINALLY } \\
\text { ECONOMIC }\end{array}$ & Margin & eserves & $\begin{array}{c}\text { Inferred } \\
\text { Marginal Reserves }\end{array}$ & & \\
\hline $\begin{array}{c}\text { SUB - } \\
\text { ECONOMIC }\end{array}$ & $\begin{array}{r}\text { Den } \\
\text { Subecono }\end{array}$ & $\begin{array}{l}\text { strated } \\
\text { Resources }\end{array}$ & $\begin{array}{c}\text { Inferred } \\
\text { Subeconomic } \\
\text { Resources }\end{array}$ & & \\
\hline
\end{tabular}

Major elements of mineral resource classification, excluding reserve base and inferred reserve base. Modified from U. S. Bureau of Mines and U. S. Geological Survey, 1980, Principles of a resource/reserve classification for minerals: U. S. Geological Survey Circular 831, p. 5. 
GEOLOGIC TIME CHART

Terms and boundary ages used in this report

\begin{tabular}{|c|c|c|c|c|c|}
\hline EON & ERA & \multicolumn{2}{|c|}{ PERIOD } & EPOCH & $\begin{array}{l}\text { BOUNDARY AGE } \\
\text { IN } \\
\text { MILLION YEARS }\end{array}$ \\
\hline \multirow{17}{*}{ Phanerozoic } & \multirow{7}{*}{ Cenozoic } & \multirow{2}{*}{\multicolumn{2}{|c|}{ Quaternary }} & Holocene & -0010 \\
\hline & & & & Pleistocene & 1,7 \\
\hline & & \multirow{5}{*}{ Tertiary } & \multirow{2}{*}{$\begin{array}{l}\text { Neogene } \\
\text { Subperiod }\end{array}$} & Pliocene & $b_{5}$ \\
\hline & & & & Miocene & \\
\hline & & & \multirow{3}{*}{$\begin{array}{l}\text { Paleogene } \\
\text { Subperiod }\end{array}$} & Oligocene & -38 \\
\hline & & & & Eocene & 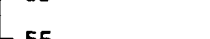 \\
\hline & & & & Paleocene & The \\
\hline & \multirow{3}{*}{ Mesozoic } & \multicolumn{2}{|c|}{ Cretaceous } & $\begin{array}{l}\text { Late } \\
\text { Early }\end{array}$ & -96 \\
\hline & & \multicolumn{2}{|c|}{ Jurassic } & $\begin{array}{l}\text { Late } \\
\text { Middle } \\
\text { Early }\end{array}$ & -138 \\
\hline & & \multicolumn{2}{|c|}{ Triassic } & $\begin{array}{c}\text { Late } \\
\text { Middle } \\
\text { Early }\end{array}$ & -205 \\
\hline & \multirow{7}{*}{ Paleozoic } & \multicolumn{2}{|c|}{ Permian } & $\begin{array}{l}\text { Late } \\
\text { Early }\end{array}$ & \\
\hline & & \multirow{2}{*}{$\begin{array}{c}\text { Carboniferous } \\
\text { Periods }\end{array}$} & Pennsylvanian & $\begin{array}{l}\text { Late } \\
\text { Middle } \\
\text { Early }\end{array}$ & 320 \\
\hline & & & Mississippian & $\begin{array}{l}\text { Late } \\
\text { Early }\end{array}$ & 360 \\
\hline & & \multicolumn{2}{|c|}{ Devonian } & $\begin{array}{c}\text { Late } \\
\text { Middle } \\
\text { Early }\end{array}$ & \\
\hline & & \multicolumn{2}{|c|}{ Silurian } & $\begin{array}{c}\text { Late } \\
\text { Middle } \\
\text { Early }\end{array}$ & \\
\hline & & \multicolumn{2}{|c|}{ Ordovician } & $\begin{array}{l}\text { Late } \\
\text { Middle } \\
\text { Early }\end{array}$ & 400 \\
\hline & & \multicolumn{2}{|c|}{ Cambrian } & $\begin{array}{c}\text { Late } \\
\text { Middle } \\
\text { Early }\end{array}$ & 500 \\
\hline \multirow{3}{*}{ Proterozoic } & Late Proterozoic & & & & \\
\hline & Middle Proterozoic & & & & \\
\hline & Early Proterozoic & & & & 10 \\
\hline \multirow{3}{*}{ Archean } & Late Archean & & & & \multirow{3}{*}{$\begin{array}{l}-3000 \\
-3400\end{array}$} \\
\hline & Middle Archean & & & & \\
\hline & Early Archean & & & & \\
\hline
\end{tabular}

'Rocks older than 570 m.y. also called Precambrian, a time term without specific rank.

2 Informal time term without specific rank. 


\section{Mineral Resources of Wilderness Study Areas- Southwestern Montana}

This volume was published as

separate chapters A-D 
DEPARTMENT OF THE INTERIOR DONALD PAUL HODEL, Secretary

U. S. GEOLOGICAL SURVEY

Dallas L. Peck, Director

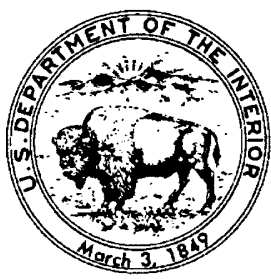




\section{CONTENTS}

[Letters designate the chapters]

(A) Mineral resources of the Ruby Mountains Wilderness Study Area, Madison County, Montana by R.G. Tysdal, G.K. Lee, J.H. Hassemer, W.F. Hanna, and S.W. Schmauch, with a section on Talc by R.B. Berg.

(B) Mineral resources of the Blacktail Mountains Wilderness Study Area, Beaverhead County, Montana, By R.G. Tysdal, G.K. Lee, J.H. Hassemer, W.F. Hanna, and J.R. Benham.

(C) Mineral Resources of the Farlin Creek Wilderness Study Area, Beaverhead County, Montana, by R.C. Pearson, J.H. Hassemer, W.F. Hanna, D.B. Hoover, H.A. Pierce, and S.W. Schmauch.

(D) Mineral resources of the Quigg West Wilderness Study Area, Granite County, Montana, by R.G. Tysdal, W.F. Hanna, and D.O. Capstick. 


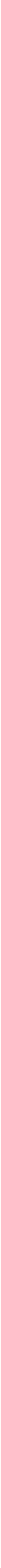




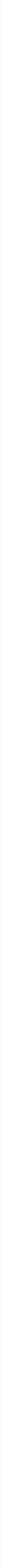


